University of Rhode Island

DigitalCommons@URI

Open Access Master's Theses

2017

\title{
Associations Between Nighttime Eating and Total Caloric Intake in College-Aged Students
}

Marissa Christina Ruginski

University of Rhode Island, mruginski@my.uri.edu

Follow this and additional works at: https://digitalcommons.uri.edu/theses

\section{Recommended Citation}

Ruginski, Marissa Christina, "Associations Between Nighttime Eating and Total Caloric Intake in CollegeAged Students" (2017). Open Access Master's Theses. Paper 1016.

https://digitalcommons.uri.edu/theses/1016

This Thesis is brought to you for free and open access by DigitalCommons@URI. It has been accepted for inclusion in Open Access Master's Theses by an authorized administrator of DigitalCommons@URI. For more information, please contact digitalcommons-group@uri.edu. 


\title{
ASSOCIATIONS BETWEEN NIGHTTIME \\ EATING AND TOTAL CALORIC INTAKE IN \\ COLLEGE-AGED STUDENTS
}

BY

MARISSA CHRISTINA RUGINSKI

\begin{abstract}
A THESIS SUBMITTED IN PARTIAL FULFILLMENT OF THE
REQUIRMENTS FOR THE DEGREE OF

MASTER OF SCIENCE IN NUTRITION AND FOOD SCIENCES
\end{abstract}

UNIVERSITY OF RHODE ISLAND

2017 


\title{
MASTER OF SCIENCE THESIS
}

OF

MARISSA CHRISTINA RUGINSKI

\section{APPROVED:}

Thesis Committee:

\author{
Major Professor Kathleen Melanson \\ Geoff Greene \\ Colleen Redding \\ Nasser H. Zawia \\ DEAN OF THE GRADUATE SCHOOL
}

UNIVERSITY OF RHODE ISLAND

2017 


\begin{abstract}
Background: Obesity is a nationwide concern across all age groups including the college-aged population. Approximately $35 \%$ of college students are reported to be overweight or obese in America, as defined by a body mass index (BMI) over $25 \mathrm{~kg} / \mathrm{m}^{2}$. Increased caloric intake has shown to be associated with an elevated BMI. Nighttime eating may be a contributing factor to increased total caloric intake, and it has been associated with higher total caloric intake and weight gain in shift workers and older adults. However, research has not examined whether an association exists between nighttime eating and total daily caloric intake in college-aged students. Nighttime eating has been identified by college students as a potential concern for weight gain, thus making this an important and novel investigation.
\end{abstract}

Objective: The primary objective was to examine possible relationships between nighttime eating and total caloric intake amongst college-aged undergraduate students at the University of Rhode Island (URI) during three consecutive semesters. The secondary objectives were to investigate associations between nighttime eating and dietary quality and sleep patterns. The exploratory objectives were to consider associations between nighttime eating and metabolic syndrome (MetS) risk and body composition. The primary hypothesis was that nighttime eaters would have a higher caloric intake.

Design and Methods: This cross-sectional data analysis was an add-on study to an ongoing secondary data analysis project that examines the relationship between diet and chronic disease risk in college-aged students, referred to as the Nutrition Assessment Secondary Data Analysis Project. Undergraduate students ( $\mathrm{n}=173,72.25 \%$ females; 
$\mathrm{BMI}=23.7 \mathrm{~kg} / \mathrm{m}^{2}$ ) completed the Nutrition Assessment Survey (NAS) to categorize nighttime eaters and assess quantitative sleep patterns. Statistically controlled for confounding variables included, gender and smoking status. The International Physical Activity Questionnaire (IPAQ) assessed activity levels. The Diet History Questionnaire (DHQ II), a web-based food frequency questionnaire, estimated total caloric intake. The DHQ II was also used to calculate the total and component scores of the Healthy Eating Index-2010 (HEI-2010), an indicator of dietary quality. Anthropometric and biochemical measures were taken to determine the students' number of risk factors for MetS and body weight status.

Results: In this population, caloric intake within 2 hours of sleep or after 10:00PM provided more accurate definitions of nighttime eating than in other populations. Caloric intake after 10:00PM and within 2 hours $\left(\mathrm{p}=.015, \mathrm{r}^{2}=.034\right)$ of sleep onset was related to higher caloric consumption (+235.56 - 543.07kcals), lower HEI-2010 total scores (-4.78 - 5.91), and more MetS risk factors.

Conclusion: This analysis aimed to determine if nighttime eating was associated with differential total daily caloric intake, along with dietary quality, sleep patterns, MetS risk, and BMI status. This study identified previously uninvestigated information regarding the prevalence of nighttime eating, along with differences in several healthrelated variables between students who engage in nighttime eating and those who do not. Nighttime eating was associated with increased caloric intake and a poorer diet quality in college students. 


\section{ACKNOWLEDGMENTS}

First and foremost a warm and kind thank you to Doctor Kathleen Melanson, my major professor, undergraduate professor, supervising professor for an undergraduate teaching assistant, and the definition of a true role model. Some may say they would not be where they are without one individual, and for myself that individual is you Dr. Melanson. I would also like to thank my committee members Dr. Geoff Greene, Dr. Colleen Redding, and my committee chair Dr. Lisa Weyandt. Last but not least a kind thank you to my parents who have supported me through this long journey. 


\section{PREFACE}

This thesis is written in Manuscript Format, following the guidelines of the Journal of American College Health. Once the preceding thesis is successfully defended it will be submitted to the Journal of American College Health for publication consideration. 


\section{TABLE OF CONTENTS}

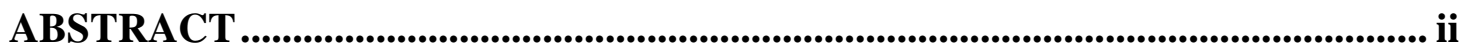

ACKNOWLEDGMENTS ................................................................................................. iv

PREFACE

TABLE OF CONTENTS................................................................................................ vi

LIST OF TABLES …......................................................................................................... viii

MANUSCRIPT

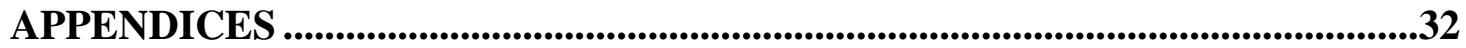

A: Review of Literature.............................................................34

B: Methods Timeline........................................................43

C: Consent Forms …................................................................44

D: Nutrition Assessment Survey.............................................48

E: International Physical Activity Questionnaire..............................55

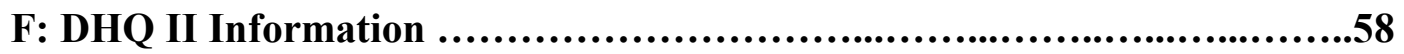

G: Biochemical Measures Document ......................................59

H: Anthropometric Instructional Document....................................60

I: Anthropometric Assessment Document...................................61

J: HEI-2010 Total Score Export Information...............................62

K: HEI-2010 Scoring Guide..............................................65

L: Table of Potential Pitfalls Identified in Thesis Proposal......................66

M: Table of Actions Taken to Manage Potential Pitfalls Identified in

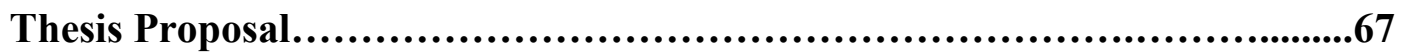




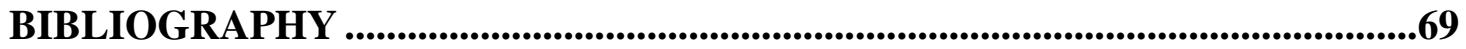




\section{LIST OF TABLES}

TABLE

PAGE

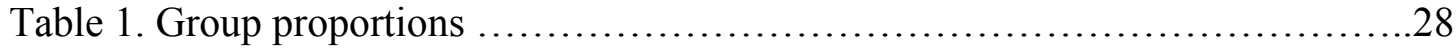

Table 2. T-test of total caloric intake by gender.................................28

Table 3. Descriptive analysis of participant demographics.......................29

Table 4. Descriptive analysis of variables of interest........................... 30

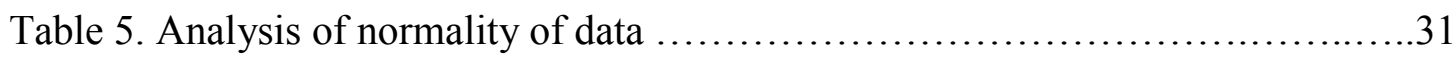

Table 6. Correlations........................................................ 31

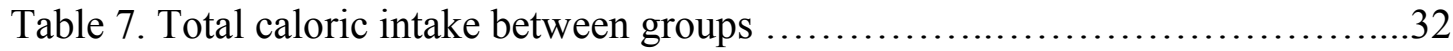

Table 8. total caloric intake between groups while controlling for gender and physical

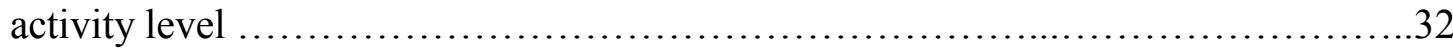

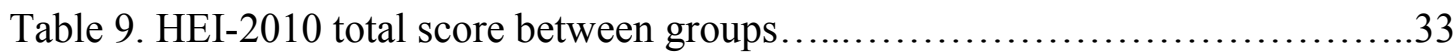

Table 10. Body fat percent separated by gender and group.........................33 


\section{MANUSCRIPT INTRODUCTION PAGE MANUSCRIPT- 1}

To be submitted to The Journal of American College Health

\section{ASSOCIATIONS BETWEEN NIGHTTIME EATING AND TOTAL CALORIC \\ INTAKE IN COLLEGE-AGED STUDENTS}

Marissa Ruginski, Kathleen Melanson

Corresponding Author: Kathleen Melanson, PhD, RD, LDN

Department of Nutrition and Food Sciences

The University of Rhode Island

Upper College Rd, Fogarty Hall

Kingston, RI 02881

Phone: 401.874 .4477

Email:kmelanson@uri.edu 


\author{
Marissa Ruginski and Kathleen J. Melanson \\ Department of Nutrition and Food Sciences, University of Rhode Island
}

Kingston, Rhode Island 02881

\begin{abstract}
Objective: To examine possible relationships between nighttime eating and total caloric intake in college-aged students, a previously unexamined population.

Participants: Data were collected on undergraduate students 18-25 years-old at the University of Rhode Island during three consecutive semesters; January 2016 - April 2017.

Methods: This cross-sectional data analysis was an add-on study to an ongoing research study. Participants completed surveys to categorize nighttime eaters, estimate total caloric intake, assess sleep patterns, demographics, physical activity, and dietary quality information. Anthropometric and biochemical measures were used to determine the number of risk factors for metabolic syndrome and assess body composition.

Results: Nighttime eating was associated with increased caloric intake and lower HEI2010 total scores $(-4.78-5.91)$, specifically intake within 2 hours $\left(p=.015, r^{2}=.034\right)$ of sleep.
\end{abstract}

Conclusion: In college students, nighttime eating was associated with increased caloric intake and poorer diet quality. 


\section{INTRODUCTION}

Obesity is a nationwide concern across all age groups including young adults attending college. According to the American College Health Association-National College Health Assessment II in Spring 2016 approximately 35\% of college students were reported to be overweight or obese in America ${ }^{1}$, as defined by a body mass index (BMI) over $24.9 \mathrm{~kg} / \mathrm{m}^{2}{ }^{1-4}$. Increased caloric intake has been found to be associated with an elevated body mass index (BMI) ${ }^{5,6}$. Nighttime eating may be a contributing factor to increased daily caloric intake; it has been associated with higher total caloric intake and weight gain in shift workers and older adults ${ }^{7-10}$. However, research has not examined this association in college-aged students ${ }^{7-10}$.

Nighttime eating has been classified by consumption of calories after a specific clock time or within a specified number of hours before sleep onset. Baron et al. classified nighttime eaters as those who consumed calories after 8:00PM or within 4 hours before sleep onset ${ }^{7,9,10}$. Nighttime eating has been identified by college students as a potential concern for weight gain, yet it has never been studied in this population 11. Therefore, relationships between nighttime eating and caloric intake were examined. Physical activity and gender affect total caloric intake, therefore both were examined in this analysis ${ }^{8}$.

Results from investigations between nighttime eating and diet quality are limited and contradicting, an association may exist for a later defined meal eating time. Reid and Baron examined nighttime eating using earlier parameters than Wang et al. and had found no difference in diet quality ${ }^{3,32,33,38}$. Breakfast consumption is often coupled with having a robust diet quality ${ }^{37}$, and in comparison breakfast skipping is associated with 
weight gain, poor diet quality, and shifting caloric intake to later in the day ${ }^{4,15,38}$. Correlations have been found between higher caloric intake after 8:00PM and a higher total daily caloric intake, shorter sleep duration, and later sleep timing ${ }^{3}$. Repeated positive associations between nighttime eating and BMI have been found ${ }^{3,32,38}$, with the exception of one study in which no correlations were found between meal timing and $\mathrm{BMI}^{33}$. This may be related to the lower BMI of the sample, and two longitudinal studies reported that nighttime eaters gained more weight over time than non-nighttime eaters 2,17. To our knowledge body composition and nighttime eating have not been examined using measured body fat percent.

The primary objective of this study was to examine possible relationships between nighttime eating and total calorie intake among undergraduate students at the University of Rhode Island (URI). The secondary objectives were to investigate associations between nighttime eating and dietary quality and sleep patterns. The exploratory objectives were to examine associations amongst nighttime eating and MetS risk and body composition.

This analysis aimed to determine if nighttime eating was related to total caloric intake, along with dietary quality, sleep patterns, metabolic syndrome (MetS) risk, and BMI status. This study identifies previously uninvestigated information regarding the prevalence of nighttime eating in college-aged students and correlations between nighttime eating and MetS risk for any aged population. 


\section{METHODS}

\section{Study Design}

Undergraduate students enrolled in a general nutrition course at URI completed a survey to identify nighttime eaters, and the validated Diet History Questionnaire II (DHQ II) was used to measure total caloric intake, the primary variable of interest ${ }^{12}$. This was a supplemental study added to an ongoing Institutional Review Board approved research project examining the relationship between diet and chronic disease risk in college-aged students, (Nutrition Assessment Study [NAS]).

Nighttime eating was defined using data collected for the NAS in addition to assessing demographics, sleep and nighttime eating. This study examined anthropometric, biochemical, and survey data on students enrolled in the Applied General Nutrition course. This was an add on study that investigated dietary data collected during three semesters, spring 2016 through spring 2017 in college-aged students.

Nighttime eating was the independent variable, and total daily caloric intake, dietary quality examined by the Healthy Eating Index-2010 (HEI-2010) total score, total hours of sleep, number of metabolic syndrome risk criteria, and BMI were dependent variables. The primary hypothesis was that college-aged students defined as nighttime eaters would have a higher total caloric intake compared to those who do not participate in nighttime eating. The secondary hypotheses were that those who were identified as nighttime eaters would have a poorer diet quality compared to those who were not identified as nighttime eaters. Additionally, a higher proportion of identified nighttime eaters would report lower sleep quantities ( $<7$ hours) compared those who 
were not identified as nighttime eaters. The exploratory hypotheses were that nighttime eaters would have more risk factors for MetS and a higher BMI status than those who were not identified as nighttime eaters.

All data collection occurred during five of the course lab sessions, with protocol guidelines in place for anthropometric, biochemical, and survey data. A timeline of data collection can be found in Appendix B. Undergraduate and graduate teaching assistants and research assistants were trained on proper protocol prior to the data collection process for anthropometric measures and other data collection techniques, and reliability of each measure was verified.

\section{Data Collection}

During the first lab, the study was explained; participating students read and signed consent forms to allow data to be used for research. Participants were required to be 18 years or older to participate; a copy of the consent form and surveys are presented in Appendices C through F. Participating students identification numbers were then entered into a password secure web portal, which provided students access where they virtually completed the NAS, DHQ II, and International Physical Activity

Questionnaire (IPAQ) surveys ${ }^{12,13}$. Anthropometric and biochemical data were entered into the NAS web portal by research assistants.

The NAS survey and IPAQ were administered during lab two. Students logged into the NAS web portal to access the survey. Biochemical data and anthropometric measurements were collected during labs three and lab four respectively; Appendices G through I. During the last visit of the protocol the students completed the DHQ II. 


\section{Variable Measurements}

\section{Nighttime Eating Categorizations: NAS Survey}

The NAS survey assessed multiple aspects of nutrition, including basic demographic information, weight satisfaction, and eating behaviors. It provided data to categorize students as nighttime eaters, and assess their sleep patterns. Specific survey items included; 'What is your usual bedtime?'; 'How many hours before bed do you usually eat your last meal or snack?' and; 'On average, how many hours of sleep do you get in a 24-hour period?'.

Nighttime eating categorizations for caloric intake after 8:00PM was computed by subtracting last meal time from reported bedtime ('What is your usual bedtime?' 'How many hours before bed do you usually eat your last meal or snack?'). Caloric intake within 4 hours of sleep was determined by the item: 'How many hours before bed do you usually eat your last meal or snack?'.

Results are reported using population appropriate categorizations of nighttime eating along with the literature defined measures of nighttime eating to demonstrate the need for newly defined categories for this population. The definition of nighttime eating was altered due to the large proportion of the sample being classified as nighttime eaters, based on the literature based definition of caloric intake after 8:00 PM (89.6\%) and intake within four hours of sleep (94.2\%); Table 1.

The nighttime eating categorizations reported are caloric intake within 2 hours of sleep and intake after 10:00PM. Categorization by specific hours (caloric intake within 2 hours) before sleep may reduce sleep time variation. Group size for intake within two hours of sleep (62.4\% nighttime eaters, $37.6 \%$ non-nighttime eaters) was 
more evenly distributed than within four hours of sleep $(62.4 \%$ nighttime eaters, $37.6 \%$ non-nighttime eaters). Additionally, significance was found in all examined variables, apart from BMI, of note significance was not found between BMI and any nighttime eating categorization. When categorizing nighttime eating by intake after 10:00 PM there was a large dietary difference in total caloric intake $(+235.56 \mathrm{kcal})$ and equal group size was observed (54.3\% nighttime eaters, $45.7 \%$ non-nighttime eaters). Lastly, significance was demonstrated in the remaining variables.

\section{Total calorie intake and Diet Quality: DHQ II}

The DHQ II was the food frequency questionnaire (FFQ) that provided an estimation of total daily caloric intake and evaluated dietary quality by providing the HEI-2010 total scores. Login to the web-based FFQ was overseen by a trained graduate teaching assistant and two undergraduate teaching assistants. Students took about one hour and 15 minutes to complete the DHQ II.

The DHQ II provided HEI-2010 total scores through an indirect statistical

analysis software output, refer to Appendices $\mathbf{J}$ through $\mathbf{K}^{15}$. The HEI-2010 is a validated dietary quality index. Correlations between HEI-2010 total scores and BMI, nutrients in the diet, and individual's self-perception of diets have been identified ${ }^{15,16}$. The DHQ II was designed and tested by the National Cancer Institute, the version utilized in this study asked about dietary patterns and intake for one year prior to completing the FFQ ${ }^{17}$.

Twenty-three participants were excluded from this analysis because they had not completed the DHQ-II, possibly due to: lab absence, error in submission, or logging off the website portal before DHQ II completion. Three participants were 
excluded from analyses due to reported intakes outside physiological possibilities, $<400$ or $>7000 \mathrm{kcals}^{18}$.

\section{Breakfast consumption: NAS Survey}

The NAS provided breakfast consumption patterns with the question; 'How many days a week do you usually eat breakfast?'. Breakfast consumers were defined as those eating breakfast at least three times weekly ${ }^{10}$.

\section{Physical activity assessment: IPAQ Short-Version}

The IPAQ assesses physical activity level (PAL) in the students; this instrument was selected as it was previously used in a cross sectional analysis on nighttime eating ${ }^{19}$, and with this age group ${ }^{20}$.

There is high over reporting associated with the IPAQ and the IPAQ scoring guide provides protocol on data truncation and outlier exclusion which was utilized when analyzing the data ${ }^{21}$. First reported combined vigorous and moderate physical activity reported more than 960 minutes were excluded from physical activity analyses

${ }^{21}$. Next, reported vigorous and moderate physical activity minutes more than 180 minutes were truncated to equate to 180 minutes ${ }^{21}$.

A total of 23 participants were excluded from physical activity analyses. Per scoring guidelines 38 cases for moderate physical activity and 53 cases for vigorous physical activity were truncated to 180 minutes ${ }^{21}$. Fourteen participants were excluded from analyses for reporting $>960$ minutes, six participants did not complete the IPAQ due to lab absence, and three entered 'Choose not to answer.' 


\section{Body Composition and Metabolic Syndrome Risk Assessment: Anthropometric and Biochemical Measures}

Height measures were taken after shoes and socks were removed, using a wall mounted stadiometer. Prior to weight measurements, using a voided digital scale, students removed any excess clothing, shoes, and socks. Height and weight measurements were taken twice and repeated until they were within $.2 \mathrm{~cm}$ and $.1 \mathrm{~kg}$ of each other. These measures were used to calculate BMI to assess weight status ${ }^{22,23}$; being overweight or obese is defined by a BMI over $24.9 \mathrm{~kg} / \mathrm{m}^{2}$ and $29.9 \mathrm{~kg} / \mathrm{m}^{2}$, respectively ${ }^{1-4}$.

Body fat percent was privately measured using the Bod Pod; following protocol preparation guidelines (Body Composition System manufactured by Life Measurements (LMI) in California). The Bod Pod utilizes air displacement plethysmography to provide a calculated estimation of body density and total body fat percentage, which involves measuring body mass and volume, and thoracic lung volume $^{24}$.

Height and weight measures (BMI) and BodPod measures were not completed on 57 participants; due to missed appointments. For one of the 57 participants information on BMI was not recorded on the form submitted to the instructor.

Hip and waist circumference were obtained using a Gulick measuring tape to determine abdominal obesity. Hip and waist measurements were taken in a private room with a separate check-in and waiting area. Waist circumference was measured at the slimmest part below the ribcage and above the iliac crest and two measures were taken; measures were repeated until they were within $.5 \mathrm{~cm}$ of each other ${ }^{3,25}$. 
Fasting biochemical data included total cholesterol, low density lipoprotein cholesterol (LDL-C), high density lipoprotein cholesterol (HDL-C), triacylglycerides (TAG), and blood glucose levels. These values were collected via a finger stick and assessed using the validated AlereCholestech ${ }^{\circledR}$ LDX System ${ }^{26,27}$. Before blood was drawn students were required to fast at least 8 to 12 hours overnight, during which time water was encouraged to ensure proper hydration ${ }^{3}$. Following the finger stick sample, participants rested for five-minutes before blood pressure was obtained with an automated computerized device (HEM-711DLX manufactured by Omron in Bannockburn, Illinois). The anthropometric and biochemical data collected allowed the researchers to determine MetS criteria. The clinical definition of MetS is having any three of the five criteria ${ }^{2}$. The criteria set forth by The American Heart Association and the National Heart, Lung, and Blood Institute include elevated blood pressure $(\geq 130 / 85 \mathrm{mmHg})$, elevated fasting blood glucose $(\geq 100 \mathrm{mg} / \mathrm{dL})$, elevated TAG $(\geq 150 \mathrm{mg} / \mathrm{dL})$, increased waist circumference (males $\geq 40$ ", females $\left.\geq 35^{\prime \prime}\right)$, and suboptimal HDL-C levels (males $\leq 40 \mathrm{mg} / \mathrm{dL}$, females $\leq 50 \mathrm{mg} / \mathrm{dL}$ ) ${ }^{2,3,28}$.

\section{Statistical Analysis}

Statistical analyses were performed using SPSS (v24). Skewness and kurtosis were used to assess normality of all variables' distribution. Correlations were run for all variables to determine any covariate influence. Previously identified covariates from the reviewed literature included age, sex, physical activity, ethnicity, current major, and smoking status 7,9,10,19,29-31.

The primary hypothesis was assessed between groups, nighttime eaters and non-nighttime eaters; using an analysis of variance (ANOVA) followed by an analysis 
of covariance (ANCOVA) using co-variates previously identified. Secondary and exploratory hypotheses were assessed using the same approaches. Total caloric intake differed significantly between genders $(\mathrm{p}=.006, \mathrm{t}=2.822)$, with males consuming more calories (+681.99kcals) (Table 2). Thus, gender was used as a covariate when analyzing the primary variable using an ANCOVA. Smoking was used as a covariate when dietary quality was analyzed as previous nighttime eating and diet quality studies have used this methodology ${ }^{3-6}$, additionally smoking was negatively associated with diet quality in adults? 


\section{RESULTS}

\section{Descriptive:}

Population sample characteristics are displayed in Table 3 and Table 4 . The final sample $(\mathrm{n}=173)$ was predominantly female $(72.25 \%)$ and Caucasian $(81.40 \%)$, with a mean age of $19.21( \pm 1.41)$ years. A small proportion $(11.56 \%, n=20)$ of the sample were nutrition majors. On average participants had a healthy BMI (23.66 \pm 3.73$)$, and $19.6 \%$ were either overweight or obese. An analysis of skewness and kurtosis demonstrated the variables were overall normally distributed; Table 5. Correlations are reported in Table 6.

\section{Primary outcome: Total daily caloric intake}

An ANOVA showed significant difference in total daily caloric intake between nighttime and non-nighttime eaters; Table 7. Those who ate within 2 hours of sleep

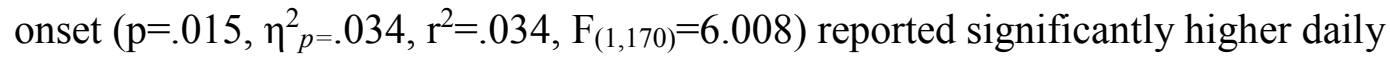
caloric consumption $(+476.26 \mathrm{kcals})$. Even after controlling for gender and PAL

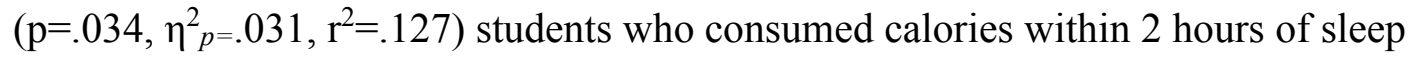
onset reported a higher daily calorie intake. Both vigorous and moderate weekly activity minutes were controlled for; Table 8 depicts the ANCOVA outcomes. As noted earlier no association was found for intake after 10:00PM.

No significant associations were found with the literature based definitions of nighttime eating; caloric intake after 8:00PM or within 4 hours of sleep. After controlling for gender and PAL, caloric differences did not statistically change; caloric intake after 8:00 PM $\left(\mathrm{p}=.370, \eta^{2}{ }_{p=.005,} \mathrm{r}^{2}=.064\right)$ or within 4 hours of sleep $(\mathrm{p}=.250$,

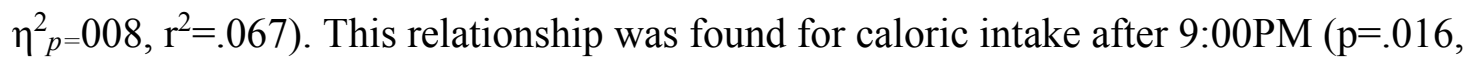




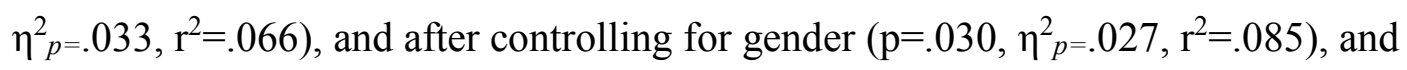
$\operatorname{PAL}\left(\mathrm{p}=.027, \eta^{2}=.033, \mathrm{r}^{2}=.043\right)$.

\section{Secondary outcome: HEI-2010 Total Score}

Nighttime eaters had a lower total HEI-2010 total score (-4.48 - 5.91) compared to non-nighttime eaters; Table 9. When categorizing nighttime eating as

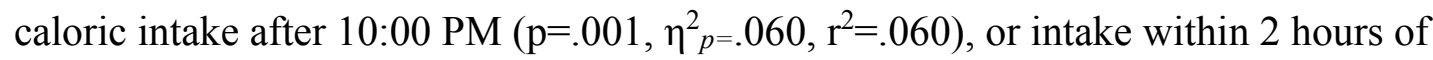

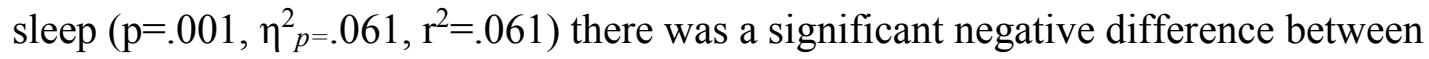
HEI-2010 total score between groups. Using the literature defined measures of nighttime eating, significance was not found; caloric intake after 8:00 PM ( $p=.145$,

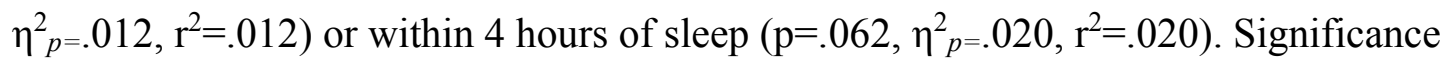
was found for caloric intake after 9:00PM $\left(\mathrm{p}=.022, \eta^{2}=.030, \mathrm{r}^{2}=.030\right)$ and having a lower HEI-2010 total score.

When controlling for smoking the association between total HEI-2010 total score remained significant for caloric intake after 10:00 $\mathrm{PM}\left(\mathrm{p}=.001, \eta^{2}{ }_{p=.064}\right.$, $\left.\mathrm{r}^{2}=.070\right)$, intake within 2 hours of sleep $\left(\mathrm{p}=.001, \eta^{2}=.064, \mathrm{r}^{2}=.069\right)$, and intake after 9:00PM ( $\left.\mathrm{p}=.019, \eta_{p=.032}^{2}, \mathrm{r}^{2}=.037\right)$. Controlling for smoking strengthened the association between HEI-2010 total score and eating within 4 hours of sleep ( $p=.055$, $\left.\eta_{p=.022,}^{2} \mathrm{r}^{2}=.027\right)$, and the association for caloric intake after 8:00PM remained nonsignificant.

\section{Sleep Quantity}

Nighttime eaters were significantly more likely to sleep less than 7 hours. Significance was found only when nighttime eating was categorized as caloric intake after 10:00 PM $\left(x^{2}=5.86, \mathrm{p}=.015\right)$. A higher percentage of nighttime eaters $(45.7 \%)$ 
reported less than seven hours of sleep each night, compared to non-nighttime eaters (27.8\%). Significance was not found for low sleep quantity and any other nighttime eating categorization.

\section{MetS}

When the number of MetS risk factor criterion was analyzed in intervals ( 0 and 1-3 risk factors) no associations were found with any nighttime eating categorizations.

\section{BMI and Body Fat Percent}

No significant differences in group means were found between BMI and all categorizations of nighttime eating. However, nighttime eating, defined as caloric intake after 10:00PM was negatively associated with body fat percent in males ($\left.13.10 \%, \mathrm{p}=.001, \eta^{2} p=321, \mathrm{r}^{2}=.321\right)$, but not in females $\left(-2.05 \%, \mathrm{p}=.192, \eta^{2}{ }_{p=.021}\right.$, $\left.\mathrm{r}^{2}=.021\right)$. Controlling for physical activity in males $\left(-16.88 \%, \mathrm{p}=.000, \eta^{2}=.477\right.$, $\left.\mathrm{r}^{2}=.490\right)$ and females $\left(-3.56 \%, \mathrm{p}=.041, \eta_{p=.064,}^{2} \mathrm{r}^{2}=.157\right)$ strengthened this relationship for both genders. When controlling for only vigorous physical activity negative body fat percent was no longer significant for female nighttime eaters ($\left.2.81 \%, \mathrm{p}=.088, \eta_{p=.042,}^{2} \mathrm{r}^{2}=.145\right)$, but remained significant for male nighttime eaters $\left(-16.99 \%, \mathrm{p}=.000, \eta^{2} p=.477, \mathrm{r}^{2}=.481\right)$. Physical activity in conjunction with nighttime eating had a negative effect on body fat percentage, primarily with males; results are displayed in Table 10. 


\section{COMMENT}

\section{Introduction}

Research previously had not examined nighttime eating prevalence and whether an association existed between nighttime eating and increased caloric intake in college-aged students. This cross-sectional data analysis explored possible relationships between new definitions of nighttime eating and a range of caloric and metabolic outcomes. This study was of particular interest since traditional definitions of nighttime eating did not apply to this population.

\section{Discussion}

This perspective study found that nighttime eaters consumed more daily calories. Nighttime eating has been consistently found to be associated with increased total daily caloric intake in adults and shift-workers ${ }^{7,9,10,30,31,34}$. Nighttime eaters consumed an average of 475-550kcals more than non-nighttime eaters and had lower HEI-2010 total scores, supporting our primary and secondary hypotheses.

As an exploratory analysis of nighttime eating in a college-aged population multiple categories of nighttime eating were calculated to explore the most appropriate definition. This exploration demonstrated a new method to define nighttime eaters in the college-aged population. The traditional nighttime eating definition of after 8:00PM or within 4 hours of sleep onset was a normal consumption time, as demonstrated by $80-90 \%$ of this sample. Consumption after 10:00PM or within 2 hours of sleep onset was a more accurate representation of nighttime eating in this population. Caloric intake within two hours of sleep represents the most accurate nighttime eating classification for this population as it eliminates sleep timing 
variation. Traditional literature classifications were based on a previously used definition of the average time of maximum caloric intake in normal eaters; both researchers continued to use this cutoff in literature published after ${ }^{7,9,10,14}$. Later categorizations of nighttime eating may be attributed to later bed timings, as the most frequently reported (34.10\%) usual bedtime was midnight. The later bed timings for college students may be due to range of studying and social events ${ }^{33}$.

This cross-sectional analysis contributes a more accurate definition of nighttime eating for college-aged students to the body of literature, with the intention to be used in further analysis of eating patterns for this population.

Nighttime eaters consuming calories within 2 hours of sleep reported significantly higher daily caloric consumption $(+476.26 \mathrm{kcals})$ in our sample. This is consistent with previous research examining total caloric intake and nighttime eating in the middle- and older-aged population and shift workers ${ }^{6-10,15,19,30,31}$, with the exception of the behavior occurring closer to sleep onset in our sample. Future studies examining associations between nighttime eating and college students should include 24-hour dietary recalls to assess the proportion of calories consumed during the nighttime period and quality of foods consumed to determine if the proportion of calories consumed is similar to findings in adults ${ }^{6-10,15,19,30,31}$.

This study assessed dietary quality based on HEI-2010 total score. Previously, relationships between diet quality and nighttime eating were examined using weekly amounts of fast food meals and sugar sweetened beverages as the measure of diet quality ${ }^{7}$. This study also found nighttime eating to be associated with a poorer diet quality ${ }^{7}$. Relationships between breakfast intake and a higher diet quality have been 
found ${ }^{35}$. Bo et al. found $76 \%$ of nighttime eaters consumed breakfast ${ }^{35}$, our study found similar proportions, with $76-79 \%$ of nighttime eaters and $86-89 \%$ of nonnighttime eaters consuming breakfast.

Along with previous research, this study has shown that eating closer to sleep onset is associated with higher total daily caloric intake ${ }^{10}$. Our study controlled for physical activity where the previously study did not ${ }^{10}$. Baron et al. found that nighttime eating defined by clock time (caloric intake after 8:00PM) was no longer related to total caloric intake or BMI after controlling for age, gender, and sleep. However, significance remained for nighttime eating when classified by hours ( caloric intake within 4 hours), which may be due to decreased sleep timing variation. Our study also demonstrated that after controlling for covariates, gender, physical activity, and smoking status, relationships between nighttime eating (caloric intake within 2 hours) and total caloric intake remained significant.

To our knowledge there is no previous literature examining MetS risk and nighttime eating in any aged population. In this sample, there was no association found between having zero or one to three MetS criteria and any nighttime eating categorization. A separate study examining MetS and college students found a low proportion of MetS in men (9.9-12\%) and women (3-6\%) ${ }^{2,3}$. Additionally, $77 \%$ of the college-aged students had one criterion of MetS. In our sample 30.05\% had one criterion of MetS ${ }^{3}$. The lower proportion in this study may be due to the fact our sample was only from one university and the other two studies examined three universities over a geographical span ${ }^{2,3}$. The lower proportion of MetS criterion may also be related to this sample being relatively healthy (BMI status and body fat 
percent), and being younger in age. Over time elevated caloric intake, may lead to development of more risk factors and/or accumulation of body weight ${ }^{7,9,36-38}$, as demonstrated with nighttime eaters in this sample and others ${ }^{7,9,10,19,31,32}$.

Limited literature, with contradicting results, has explored the possible relationships between nighttime eating and $\mathrm{BMI}{ }^{10,19}$. This study found no associations between BMI and nighttime eating, but when body composition was examined using body fat percent a negative association was found for nighttime eating after 10:00PM. Similarly, other studies have found no correlations with meal timing and BMI ${ }^{10}$, this may be related to the lower BMI of the sample in previous studies ${ }^{10,37}$, and in this analysis, with $19.6 \%$ being either overweight or obese. Even though no relationship with BMI was found, nighttime eating after 10:00PM was associated with a lower body fat percentage $(-5.45 \%)$; over time higher caloric intake is likely to lead to weight gain unless offset by energy expenditure ${ }^{10,37}$. Future studies should include questions to assess timing of exercise and whether the participant is a student athlete. Additionally, determining if nighttime eating is a new behavior adapted in college from adjusting to studying, social events, or psychological reasons ${ }^{33}$, or if the eating behavior was adapted over time may explain the negative association between body fat percentage and nighttime eating.

Nighttime eating and sleep duration are correlated and may be related to the mechanism for increased weight gain from increased caloric intake due to habitual nighttime eating ${ }^{3}$. This may be because decreased sleep duration is associated with hormonal disturbances; decreased leptin and increased ghrelin ${ }^{14}$. These hormonal changes may impact one's weight status, as ghrelin increases appetite and leptin 
reduces appetite ${ }^{14}$. Short sleep duration, linked to nighttime eating, was correlated with emotional disturbances such as stress and pessimism, which may decrease one's ability to adhere to dietary and physical activity regiments and thus impact one's weight status ${ }^{3,14}$.

An increase in total caloric intake related to nighttime calorie intake may be due to the decreased satiety associated with late night food consumption, this is known as the satiety ratio principle $9,30,31$. The satiety ratio is a decrease in satiety efficiency throughout the day ${ }^{30}$. The satiety ratio principle was demonstrated by de Castro, where an increase in time spent eating and meal size occurred over the progression of the day ${ }^{30}$. Additionally, the after-meal interval decreased, even though more calories had been consumed in meals ${ }^{30}$. This study showed that as the day progresses, individuals spent more time eating food and less time in between meals, even though more calories were consumed at those later meals ${ }^{30}$. This demonstrates that one's satiety level is not as greatly impacted with later meals compared to meals consumed earlier in the day ${ }^{30}$.

\section{Limitations:}

This was a cross-sectional data analysis therefore causation cannot be inferred from the results. Future research should utilize longitudinal trials. The sample used was a convenience sample, allowing us to examine nighttime eating in a the college population for the first time. Since the sample was primarily female, future studies should recruit a more diverse and representative college student population sample.

The independent variable, nighttime eating, was assessed by asking proximity of consumption to sleep onset and relative to clock-time. These questions have not 
been validated in this study or in any other study of nighttime eating. This is a limitation within the research as there is no validated measure to assess nighttime, eating apart from a questionnaire that serves as a psychiatric diagnostic tool for nighttime eating syndrome ${ }^{8}$. Thus, this is an area of future work.

Reliability of self-reported dietary data was a limitation to this study. However, since the nutrition course material includes portion estimation lessons, this population had more background to estimate portion sizes than a lay person. The DHQ II was not administered until the $10^{\text {th }}$ week of the academic semester, therefore participants had 10 weeks of exposure to general nutrition information at a college level, and short term portion size lessons have been shown to increase the accuracy of college-aged students' portion size estimates ${ }^{39}$. These students elected to enroll in a nutrition course and may have been a biased sample. The lower proportion of MetS criterion may also be related to this sample being relatively healthy (BMI status and body fat percent), and younger in age; potential pitfalls are discussed in Appendices L through $\mathbf{M}$.

\section{Strengths}

The comparable nighttime eating studies primarily examine the middle-aged population and shift workers ${ }^{7,9,10,19,31}$, whereas this study examined the college-aged population. This is the first known study to explore the prevalence of nighttime eating in this population, and to explore relationships between MetS and nighttime eating. Additionally, HEI-2010 total score was used as our assessment of diet quality rather than non-validated measures that have been used ${ }^{40,41}$. Further measures of body fat percent, BMI, and blood objectively reflected health status. 


\section{Conclusion}

Nighttime eating, specifically caloric intake within 2 hours of sleep onset, was related to higher caloric consumption $(+476.26 \mathrm{kcals})$, and lower HEI-2010 total scores $(-5.91)$ in the college aged population. 


\section{REFERENCES}

1. American College Health Association. American College Health AssociationNational College Health Assessment II: reference group executive summary spring 2016 2016:21.

2. Morrell JS, Byrd-Bredbenner C, Quick V, Olfert M, Dent A, Carey G. Metabolic syndrome: comparison of prevalence in young adults at 3 land-grant universities. J Am Coll Health. 2014;62(1):10.

3. Morrell JS, Lofgren IE, Burke J, Reilly R. Metabolic syndrome, obesity, and related risk ractors among college men and women. $J$ Am Coll Health. 2012;60(1):9.

4. Winklebey MA, Cubbin C. Changing patterns in health behaviors and risk factors related to chronic diseases, 1990-2000. Behavior Change. 2004;19(1):8.

5. Al-Isa AN, Wijesekara N, Desapriya E. Multiple factors contribute to obesity among Kuwaiti college women. Health. 2013;05(05):943-952.

6. Garaulet M, Gomez-Abellan P, Alburquerque-Bejar JJ, Lee YC, Ordovas JM, Scheer F. Timing of food intake predicts weight loss effectiveness. Int J Obes (Lond). 2013;37(4):604-611.

7. Baron KG, Reid KJ, Kern AS, Zee P. Role of sleep timing in caloric intake and BMI. Obesity (Silver Spring). 2011;19(7):1374-1381.

8. Kinsey AW, Ormsbee M. The health impact of nighttime eating: old and new perspectives. Nutrients. 2015;7(4):2648-2662.

9. Reid KJ, Baron KG, Horn LV, Zee P. Contribution of evening macronutrient intake to total caloric intake and body mass index. Appetite. 2013;60(1):246251.

10. Reid KJ, Baron KG, Zee PC. Meal timing influences daily caloric intake in healthy adults. Nutr Res. 2014;34(11):930-935. 
11. Nelson MC, Story M. Food environments in university dorms: 20,000 calories per dorm room and counting. Am J Prev Med. 2009;36(6):523-526.

12. Beasley JM, Davis A, Riley W. Evaluation of a web-based, pictorial diet history questionnaire. Public Health Nutr. 2009;12(5):651-659.

13. Rangul V, Holmen TL, Kurtze N, Cuypers K, Midthjell K. Reliability and validity of two frequently used self-administered physical activity questionnaires in adolescents. BMC Med Res Methodol. 2008;8:47.

14. Boston RC, Moate PJ, Allison KC, Lundgren JD, Stunkard AJ. Modeling circadian rhythms of food intake by means of parametric deconvolution: results from studies of the night eating syndrome. Am J Clin Nutr. 2008;87:5.

15. Sato-Mito N, Sasaki S, Murakami K, et al. The midpoint of sleep is associated with dietary intake and dietary behavior among young Japanese women. Sleep Med. 2011;12(3):289-294.

16. Gil A, Martinez de Victoria E, Olza J. Indicators for the evaluation of diet quality. Nutr Hosp. 2015;31 Suppl 3:128-144.

17. Subar AF, Kipnis V, Troiano RP, et al. Using intake biomarkers to evaluate the extent of dietary misreporting in a large sample of adults: the OPEN study. American Journal of Epidemiology. 2003;158(1):13.

18. Vadiveloo M, Dixon LB, Mijanovich T, Elbel B, Parekh N. Dietary variety is inversely associated with body adiposity among US adults using a novel food diversity index. $J$ Nutr. 2015;145(3):555-563.

19. Wang JB, Patterson RE, Ang A, Emond JA, Shetty N, Arab L. Timing of energy intake during the day is associated with the risk of obesity in adults. $J$ Hum Nutr Diet. 2014;27 Suppl 2:255-262. 
20. Greaney ML, Less FD, White AA, et al. College students' barriers and enablers for healthful weight management: a qualitative study. J Nutr Educ Behav. 2009;41(4):281-286.

21. Guidelines for data processing and analysis of the International Physical Activity Questionnaire (IPAQ): short and long forms. IPAQ website http://www.ipaq.ki.se/scoring.pdf. Updated 2005. Accessed December 13th, 2016

22. Raynor HA, Champagne CM. Position of the academy of nutrition and dietetics: interventions for the treatment of overweight and obesity in adults. $J$ Acad Nutr Diet. 2016;116(1):129-147.

23. Ogden CL, Carroll MD, Kit BK, Flegal KM. Prevelance of obesity among adults: United States, 2011-2012. NCHS Data Brief. 2013;131.

24. McCrory MA GT, Bernauer EM, Mole PA. . Evaluation of a new air displacement plethysmograph for measuring human body composition. Med Sci Sports Exer. 1995;27(12):1686-1691.

25. Lohman TG, Roche AF, Martorell R. Anthropometric Standardization Reference Manual. Champaign, IL: Human Kinetics Books; 1988.

26. Dale RA, Jensen LH, Krantz MJ. Comparison of two point-of-care lipid analyzers for use in global cardiovascular risk assessments. Ann Pharmacother. 2008;42(5):6.

27. Carey M, Markham C, Gaffney P, Boran C, Maher V. Validation of a point of care lipid analyser using a hospital based reference laboratory. Ir J Med Sci. 2006;175(4):5.

28. Grundy SM, Cleeman JI, Daniels SR, et al. Diagnosis and management of the metabolic syndrome: an American Heart Association and National Heart, Lung, and Blood Institute Scientific Statement. Circulation. 2005;112(17):2735-2752. 
29. Flegal, KM, Graubard, BI Williamson, DF, Gail, MH. Excess deaths associated with underweight, overweight, and obesity. JAMA. 2005;293(15):1861-1867,

30. de Castro J. The time of day of food intake influences overall intake in humans. J Nutr. 2004;134:8.

31. de Castro JM. The time of day and the proportions of macronutrients eaten are related to total daily food intake. Br J Nutr. 2007;98(5):1077-1083.

32. Mills JP, Perry CD, Reicks M. Eating frequency is associated with energy intake but not obesity in midlife women. Obesity (Silver Spring).

2011;19(3):552-559.

33. Wang J, Yeh K. Research on staying up of college students: an example of students in NCCU. NCCU; 2013.

34. Bo S, Musso G, Beccuti G, et al. Consuming more of daily caloric intake at dinner predisposes to obesity. A 6-year population-based prospective cohort study. PLoS One. 2014;9(9):e108467.

35. Andersen GS, Stunkard AJ, Sorensen TI, Petersen L, Heitmann BL. Night eating and weight change in middle-aged men and women. Int J Obes Relat Metab Disord. 2004;28(10):1338-1343.

36. Gluck M, Venti C, Salbe A, Krakoff J. Nighttime eating: commonly observed and related to weight gain in an inpatient food intake study. Am J Clin Nutr. 2008;88:5.

37. Patel SR, Malhotra A, White DP, Gottlieb DJ, Hu FB. Association between reduced sleep and weight gain in women. Am J Epidemiol. 2006;164(10):947954.

38. Byrd-Bredbenner C, Schwartz J. The effect of practical portion size measurement aids on the accuracy of portion size estimates made by young adults. J Hum Nutr Diet. 2004;17:6. 
39. Guenther PM, Casavale KO, Reedy J, et al. Update of the Healthy Eating Index: HEI-2010. J Acad Nutr Diet. 2013;113(4):569-580.

40. Guenther PM, Kirkpatrick SI, Reedy J, et al. The Healthy Eating Index-2010 is a valid and reliable measure of diet quality according to the 2010 Dietary Guidelines for Americans. J Nutr. 2014;144(3):399-407. 


\section{Tables}

Table 1. Group proportions

\begin{tabular}{|lrr|}
\hline Classifications of Nighttime Eating & Nighttime Eaters & \multicolumn{1}{l}{ Non-Nighttime Eaters } \\
& $\mathrm{N}(\%)$ & $\mathrm{N}(\%)$ \\
Caloric Intake after 8:00PM & $155(89.6 \%)$ & $18(10.4 \%)$ \\
Caloric Intake after 9:00PM & $133(76.9 \%)$ & $40(23.1 \%)$ \\
Caloric Intake after 10:00PM & $94(54.3 \%)$ & $79(45.7 \%)$ \\
Caloric Intake after 11:00PM & $66(38.2 \%)$ & $107(61.8 \%)$ \\
Within 4 Hours Sleep & $163(94.2 \%)$ & $10(5.8 \%)$ \\
Within 3 Hours Sleep & $141(81.5 \%)$ & $32(18.5 \%)$ \\
Within 2 Hours Sleep & $108(62.4 \%)$ & $65(37.6 \%)$ \\
Within 1 Hour Sleep & $51(29.5 \%)$ & $122(70.5 \%)$ \\
\hline
\end{tabular}

Table 2. T-test of total caloric intake by gender

\begin{tabular}{|c|c|c|c|}
\hline & Mean caloric intake & $\mathrm{p}$ & $\mathrm{t}$ \\
\hline Male & 2703.66 & $.006 *$ & 2.822 \\
\hline Female & 2021.66 & & \\
\hline Mean Difference (kcal) & -681.99 & & \\
\hline $\mathrm{N}=$ & 173 & & \\
\hline$* \mathrm{P}<0.05$ significance & & & \\
\hline
\end{tabular}


Table 3. Descriptive Analysis of Participant

Demographics

\begin{tabular}{|c|c|c|}
\hline & Mean & SD \\
\hline \multirow[t]{2}{*}{ Age } & 19.21 & 1.41 \\
\hline & $\mathbf{N}$ & $\%$ \\
\hline \multicolumn{3}{|l|}{ Gender } \\
\hline Male & 48 & 27.75 \\
\hline Female & 125 & 72.25 \\
\hline \multicolumn{3}{|l|}{ BMI Status } \\
\hline Underweight & 5 & 2.9 \\
\hline Normal weight & 110 & 63.6 \\
\hline Overweight & 27 & 15.6 \\
\hline Obese & 7 & 4.0 \\
\hline \multicolumn{3}{|l|}{ Ethnicity } \\
\hline Caucasian & 140 & 81.40 \\
\hline Hispanic/Latin & 16 & 9.30 \\
\hline Mixed & 8 & 4.65 \\
\hline African American & 3 & 1.74 \\
\hline Asian & 4 & 2.33 \\
\hline Chose Not to Answer & 2 & 1.16 \\
\hline \multicolumn{3}{|l|}{ School Year } \\
\hline Freshman & 91 & 52.6 \\
\hline Sophomore & 48 & 27.75 \\
\hline Junior & 26 & 15.03 \\
\hline Senior & 8 & 4.62 \\
\hline \multicolumn{3}{|l|}{ Smoking Status } \\
\hline Smoker & 31 & 17.92 \\
\hline Non-Smoker & 142 & 82.08 \\
\hline
\end{tabular}


Table 4. Descriptive Analysis of Variables of Interest

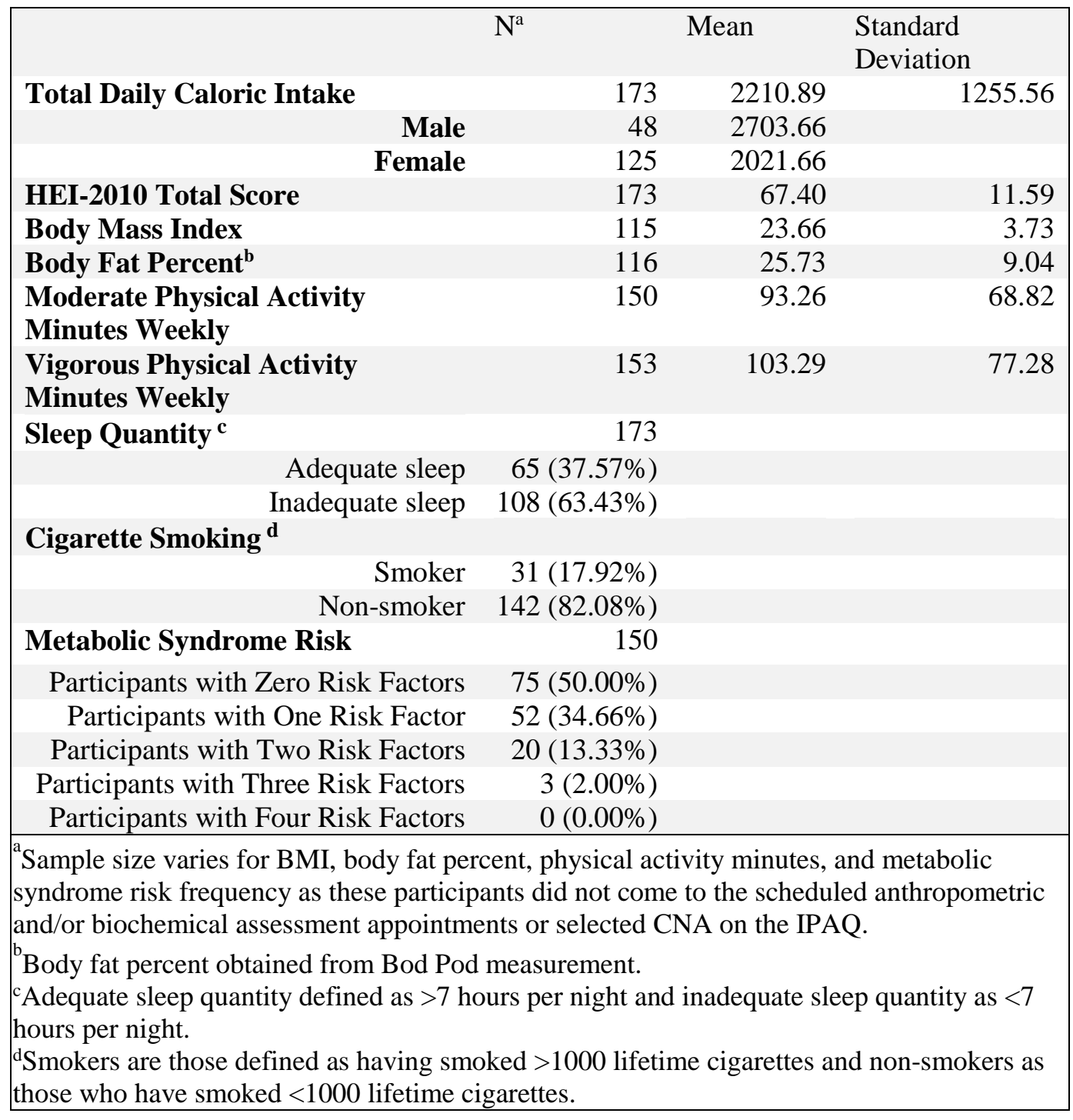


Table 5. Analysis of Normality of Data

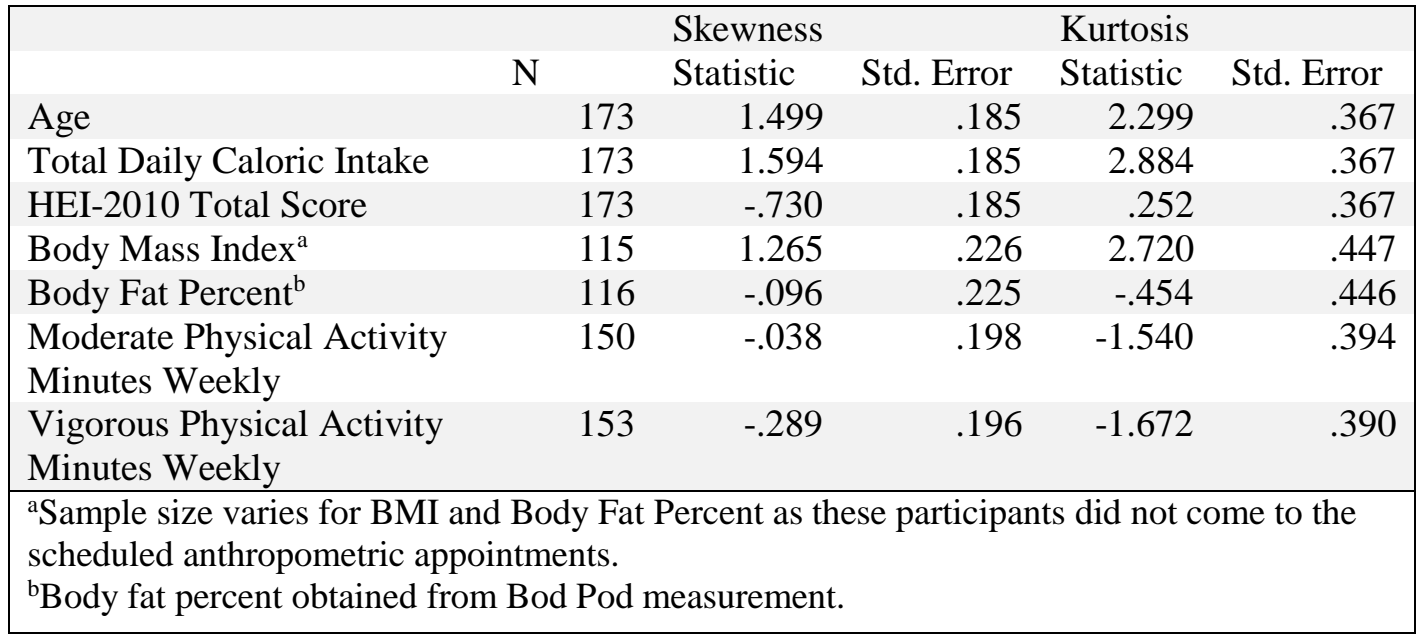

Table 6. Correlations

\begin{tabular}{|c|c|c|c|c|c|c|c|}
\hline & $\begin{array}{l}\text { Total } \\
\text { caloric } \\
\text { intake }\end{array}$ & $\begin{array}{l}\text { HEI- } \\
2010 \\
\text { Total } \\
\text { Score }\end{array}$ & Age & BMI & $\begin{array}{l}\text { Body } \\
\text { Fat } \\
\text { Percent }\end{array}$ & $\begin{array}{l}\text { Vigorous } \\
\text { Physical } \\
\text { Activity } \\
\text { Minutes }\end{array}$ & $\begin{array}{l}\text { Moderate } \\
\text { Physical } \\
\text { Activity } \\
\text { Minutes }\end{array}$ \\
\hline $\begin{array}{l}\text { Total caloric } \\
\text { intake }\end{array}$ & & & & & & & \\
\hline $\begin{array}{l}\text { HEI-2010 Total } \\
\text { Score }\end{array}$ & $-.231 * *$ & & & & & & \\
\hline Age & .063 & .073 & & & & & \\
\hline BMI & .044 & -.039 & .130 & & & & \\
\hline Body Fat Percent & $-.246^{* *}$ & -.080 & $-.234 *$ & $.472 * *$ & & & \\
\hline $\begin{array}{l}\text { Vigorous } \\
\text { Physical Activity } \\
\text { Minutes }\end{array}$ & -.096 & $.218 * *$ & .052 & -.075 & $-.251 * *$ & & \\
\hline $\begin{array}{l}\text { Moderate } \\
\text { Physical Activity } \\
\text { Minutes }\end{array}$ & -.105 & .043 & -.035 & -.039 & -.109 & & \\
\hline
\end{tabular}


Table 7. Total caloric intake between groups

\begin{tabular}{|c|c|c|c|c|c|c|c|c|}
\hline $\begin{array}{l}\text { Categorization } \\
\text { of Nighttime } \\
\text { Eating }\end{array}$ & $\begin{array}{l}\text { Nighttime } \\
\text { Eater } \\
\text { Mean(SD) } \\
\mathrm{n}=\end{array}$ & $\begin{array}{l}\text { Non- } \\
\text { Nighttime } \\
\text { Eater } \\
\text { Mean(SD) } \\
n=\end{array}$ & $\begin{array}{l}\text { Difference } \\
(\mathrm{kcal})\end{array}$ & df & $\mathrm{F}$ & $\mathrm{p}$ & $\eta 2 \mathrm{p}$ & $\mathrm{r}^{2}$ \\
\hline $\begin{array}{l}\text { Caloric intake } \\
\text { after 10:00PM }\end{array}$ & $\begin{array}{r}2318.46 \\
(1351.17) \\
\mathrm{n}=94\end{array}$ & $\begin{array}{r}2082.90 \\
(1126.46) \\
n=79\end{array}$ & +235.56 & 1 & 1.510 & .220 & .009 & .009 \\
\hline $\begin{array}{l}\text { Caloric intake } \\
\text { within } 2 \text { hours } \\
\text { sleep }\end{array}$ & $\begin{array}{r}2389.46 \\
(1418.30) \\
n=108\end{array}$ & $\begin{array}{r}1913.57 \\
(854.24) \\
\mathrm{n}=65\end{array}$ & +476.26 & 1 & 6.008 & $.015^{*}$ & .034 & .034 \\
\hline $\begin{array}{l}\text { Caloric intake } \\
\text { after 9:00PM }\end{array}$ & $\begin{array}{r}2336.46 \\
(1336.81) \\
n=133\end{array}$ & $\begin{array}{r}1793.37 \\
(819.39) \\
n=40\end{array}$ & +543.07 & 1 & 5.918 & $.016^{*}$ & .033 & .033 \\
\hline $\begin{array}{l}\text { Caloric intake } \\
\text { after 8:00PM }\end{array}$ & $\begin{array}{r}2252.30 \\
(1418.30) \\
n=155\end{array}$ & $\begin{array}{r}1854.26 \\
(1418.30) \\
n=18\end{array}$ & +398.04 & 1 & 1.627 & .204 & .009 & .009 \\
\hline $\begin{array}{l}\text { Caloric intake } \\
\text { within } 4 \text { hours } \\
\text { sleep }\end{array}$ & $\begin{array}{r}2240.61 \\
(1418.30) \\
n=163\end{array}$ & $\begin{array}{r}1726.44 \\
(1418.30) \\
n=10\end{array}$ & +514.17 & 1 & 1.585 & .210 & .009 & .009 \\
\hline
\end{tabular}

Table 8. Total caloric intake difference between groups, controlling for gender and physical activity level

\begin{tabular}{|c|c|c|c|c|c|c|c|}
\hline $\begin{array}{l}\text { Categorization of } \\
\text { Nighttime Eating }\end{array}$ & $\begin{array}{l}\text { Nighttime } \\
\text { Eater } \\
\text { Mean(SD) } \\
\mathrm{n}^{\mathrm{a}}=\end{array}$ & $\begin{array}{l}\text { Non- } \\
\text { Nighttime } \\
\text { Eater } \\
\text { Mean(SD) } \\
\mathrm{n}=\end{array}$ & $\mathrm{df}$ & $\mathrm{F}$ & $\mathrm{p}$ & $\eta 2 \mathrm{p}$ & $\mathrm{r}^{2}$ \\
\hline $\begin{array}{l}\text { Caloric intake after } \\
\text { 10:00PM }\end{array}$ & $\begin{array}{r}2274.89 \\
(1349.57) \\
n=82\end{array}$ & $\begin{array}{r}2100.74 \\
(1180.38) \\
n=66\end{array}$ & 1 & .392 & .532 & .003 & .101 \\
\hline $\begin{array}{l}\text { Caloric intake within } \\
2 \text { hours of sleep }\end{array}$ & $\begin{array}{r}2362.07 \\
(1441.00) \\
n=94\end{array}$ & $\begin{array}{r}1910.28 \\
(858.82) \\
n=54\end{array}$ & 1 & 4.607 & $.034 *$ & .031 & .127 \\
\hline $\begin{array}{l}\text { Caloric intake after } \\
\text { 9:00PM }\end{array}$ & $\begin{array}{r}2323.87 \\
(1371.28) \\
\mathrm{n}=111\end{array}$ & $\begin{array}{r}1817.31 \\
(837.29) \\
n=37\end{array}$ & 1 & 2.986 & .086 & .020 & .117 \\
\hline $\begin{array}{l}\text { Caloric intake after } \\
\text { 8:00PM }\end{array}$ & $\begin{array}{r}2244.71 \\
(1316.36) \\
n=130\end{array}$ & $\begin{array}{r}1854.26 \\
(883.17) \\
n=18\end{array}$ & 1 & .515 & .474 & .004 & .102 \\
\hline $\begin{array}{l}\text { Caloric intake within } \\
4 \text { hours of sleep }\end{array}$ & $\begin{array}{r}2231.34 \\
(1298.77) \\
n=138\end{array}$ & $\begin{array}{r}1726.44 \\
(798.16) \\
n=10\end{array}$ & 1 & .912 & .341 & .006 & .105 \\
\hline
\end{tabular}




\section{APPENDICES}

\section{APPENDIX A: Review of Literature}

\section{Obesity:}

Obesity is measured through body mass index (BMI), a BMI greater than $30 \mathrm{~kg} / \mathrm{m}^{2}$ is considered an obese status, and a BMI between 25 to $29.9 \mathrm{~kg} / \mathrm{m}^{2}$ is considered an overweight status ${ }^{29,31}$. Currently $60 \%$ of the total United States

population is either overweight or obese ${ }^{31}$, in college aged students the prevalence is $35 \%$, which is less than the national prevalence ${ }^{1}$. Young adults are coming from an age group (2-17 year olds) that weighs more than their ancestors did during those years of life ${ }^{6}$.

This is problematic as obesity earlier in life has been found to increase the risk for chronic diseases in adulthood, including cancers, diabetes, cardiovascular disease, mobility limitations, and arthritis ${ }^{21,22,35}$. College students have identified many barriers to healthful weight control, including nighttime eating, social stimulations such as going out to eat, alcohol consumption, and peer influences that hinder healthful behaviors. Environmental barriers were also identified, including over availability of food in dining halls, large portion sizes offered, fast food accessibility, emotional eating, and lack of time and healthful food options ${ }^{8,19,26,28}$.

College-aged students are of interest due to their overall declining health profile; increased obesity rates in all gender and racial/ethnic groups, decreased fruit and vegetable intake, and higher levels of sedentary behavior ${ }^{20,39}$. In young adults (18-25 years old), obesity is overshadowed by health risks 
associated with sexual violence or substance abuse and the fact that most college-aged students do not view themselves at risk for chronic disease later in life $^{26}$. Longitudinal studies have found college students can gain an average of $4.3 \mathrm{~kg}$ over the traditional four-year length of college and thus are at risk for weight gain ${ }^{21}$.

\section{Nighttime eating:}

The literature based definition of nighttime eating is defined as any caloric intake after 8:00PM or within four hours of sleep onset, 8:00PM has been defined as the average time of maximum caloric intake for persons without an eating disorder ${ }^{3,32,33}$. Multiple mechanisms may explain nighttime calorie intake as a predictor for weight gain from increased total caloric intake 9,10,13,15,23,32,33,38 . In middle aged shift workers, nighttime calorie intake has shown to decrease total energy expenditure, with a reduction in resting metabolic rate (RMR) as the possible mechanism (15). Having a lower relative RMR may be a predictor to an elevated BMI or increase the risk of future weight gain ${ }^{24}$. During the evening fat oxidation is reduced, this may be another mechanism related to increased weight gain with nighttime eating ${ }^{24}$.

Nighttime eating and sleep duration are correlated ${ }^{3}$. Decreased sleep duration is associated with hormonal disturbances, including decreased leptin and increased ghrelin ${ }^{14}$. These hormonal changes may impact one's weight status, as ghrelin increases appetite and leptin reduces appetite ${ }^{14}$. Short sleep duration, linked to nighttime eating, was found to be correlated with emotional disturbances such as stress and pessimism ${ }^{3,14}$. These disturbances may decrease 
one's ability to adhere to dietary and physical activity regiments and thus impact one's weight status ${ }^{3,14}$.

An increase in total caloric intake related to nighttime calorie intake may be due to the decreased satiety of late night food consumption, which is known as the satiety ratio principle $9,10,32$. The satiety ratio principle is described as a decrease in satiety efficiency throughout the day ${ }^{10}$. The satiety ratio principle was demonstrated by de Castro, where an increase in meal time and size occurred over the progression of the day ${ }^{10}$. Additionally, the after-meal interval decreased, even though more calories had been consumed in the meals. This study showed that as the day progresses individuals spent more time eating food and less time in between meals, even though more calories were consumed at those later meals. This demonstrates that one's satiety level is not as greatly impacted with later meals compared to meals consumed earlier in the day ${ }^{10}$. It is also theorized that higher total caloric intake related to nighttime eating may have an evolutionary basis, in which there are increased opportunities to eat into the night hours due to technological advances ${ }^{9,10}$.

\section{Nighttime eating and total calorie intake:}

Nighttime eating has been consistently found to be associated with increased total daily caloric intake ${ }^{3,9,10,25,32,33}$. Over time, higher caloric intake related to nighttime eating was positively associated with weight gain ${ }^{2,17}$. The evidence for a higher BMI is variable amongst studies, with most finding a positive association $^{3,32,38}$, with the exception of one ${ }^{33}$. All researchers had 
examined an adult population, with a mean age of 30; none targeted the collegeaged population $3,9,10,25,32,33$.

Wang et al. controlled for confounding variables (gender, age, total calorie intake, education level, body size, physical activity, and over/underreporting) and examined nighttime eating by using the proportion of calories consumed at meal times to analyze total caloric intake ${ }^{38}$. In the study a web based dietary recall system was used to assess total caloric intake and timing of intake $^{38}$. It was found that those who consumed more than $33 \%$ of their total caloric intake in the evening were twice as likely to be obese ${ }^{38}$. It was not investigated whether the nighttime eaters $(>33 \%$ total caloric intake between 5:00PM-12:00AM) had higher total daily caloric intakes, but it was found that participants consuming a higher proportion of their calories during the evening were more likely to be obese ${ }^{38}$.

Wang et al. was not the first to investigate nighttime eating in the middle-aged population using proportions of energy intake ${ }^{38}$, de Castro did as well $^{9,10}$. In de Castro's studies, it was found that caloric intake was highest between the hours of 6:00PM-10:00PM after removing calories consumed from beverages ${ }^{10}$. These results were then replicated by de Castro and a positive association was found with and without removal of beverage calories ${ }^{9}$. Additionally, the subjects who engaged in nighttime eating had a higher total caloric intake compared to those who did not eat at nighttime ${ }^{9,10}$. 


\section{Nighttime eating and BMI:}

Repeated positive associations between nighttime eating and BMI have been found ${ }^{3,32,38}$, additionally nighttime eaters have been found to gain more weight over time than non-nighttime eaters ${ }^{2,17}$. Gluck measured participants at a $3.4( \pm 1.8)$ year follow-up visit, and found significant weight gain in nighttime eaters ${ }^{17}$. As part of an 11-year prospective study, Andersen et al. found an association between nighttime eating and weight gain in individuals who previously had a higher BMI ${ }^{2}$. Reid et al. found that eating one's last meal later in the day and eating closer to sleep onset were associated with greater total caloric intake, though there were no correlations were found with meal timing and $\mathrm{BMI}{ }^{33}$. This may be related to the lower BMI of the sample, not controlling for sleep duration, or not distinguishing reliable reporters from the general sample ${ }^{17,33}$. Additionally, even though no relationship was found over time higher caloric intake may lead to weight gain ${ }^{17,33}$.

Other studies have previously found an association between nighttime eating, total calorie intake and BMI when controlling for sleep duration ${ }^{3,32}$. Wang et al. found significance between total caloric intake and BMI, with the reliable reporters identified by doubly labeled water ${ }^{38}$. As weight gain is a concern for the college-aged population, and nighttime eating has been identified by students as a barrier to weight management this was a novel association to investigate in this age group. 


\section{Nighttime eating and diet quality:}

Investigations into a relationship between nighttime eating and diet quality are limited and contradicting ${ }^{3,38}$. Diet quality is the total measure of high quality eating patterns in a diet, such as higher fruit and vegetable and lower processed food intake ${ }^{3,36}$. Total caloric intake has primarily been examined in nighttime eating studies, while research on diet quality has been overlooked ${ }^{9,10}$.Wang et al. found no association in the percentage of calories from fat, protein, or carbohydrate, grams of fiber, and servings of fruits or vegetables per a day between participants who consumed $<30 \%$ of their total calories in the evening (or any meal period) and those who consumed $>30 \%$ of kcals in evening ${ }^{38}$. Reid and Baron found that middle aged late sleepers had later meal timings for breakfast, lunch, dinner, and last meal, and poorer diet quality, which was defined as increased intake of sugar sweetened beverages and fast food ${ }^{3}$.

Further investigations into possible relationships between nighttime eating and diet quality are needed. An association may exist for a later defined meal eating time, as Reid and Baron examined nighttime eating in the parameters of caloric consumption after 8:00PM or within four hours before sleep, whereas Wang used between 5:00PM-12:00AM as cutoff points ${ }^{3,32,33,38}$.

Breakfast consumption is often coupled with having a robust diet quality and is a preventative factor for weight gain ${ }^{37}$. Breakfast skipping is associated with weight gain, poor diet quality, and shifting caloric intake to later in the day 4,15,38. Baron et al. looked at nighttime eating in late and non-late sleepers and 
found no significant difference in outcomes for those who did or did not consume breakfast ${ }^{33}$. A study done in the Mediterranean on 520 adults averaging 41 years old found that nighttime eaters frequently skipped breakfast ${ }^{15}$, whereas Bo et al. found $76 \%$ of nighttime eaters consumed breakfast ${ }^{4}$. The variability of findings for relationships between nighttime eating and breakfast consumption warrant further investigation, furthermore most research designs focus on the younger school age population for breakfast consumption studies 38.

\section{Nighttime eating and sleep quality:}

It has been continuously found that adolescent late sleepers, compared to non-late sleepers, had a poorer diet quality ${ }^{11,16,18,34}$. Additionally, caloric consumption after 8:00PM was found to be associated with a later sleeping time, shorter sleep duration, and elevated BMI ${ }^{3}$. Those with a short sleep duration, less than 7 hours of sleep, have a greater likelihood of being obese or experiencing weight gain ${ }^{2,12,14}$. Gangwisch examined epidemiological data on all age groups and found short sleep duration was associated with weight gain and obesity, decreased leptin and increased ghrelin levels, and emotional disturbances, including stress and pessimism ${ }^{14}$. A 16-year prospective study on middle aged women found a shorter sleep duration increased the relative risk for modest weight gain and obesity in middle-aged persons ${ }^{30}$. Correlations were also found among elevated BMI and later sleep timing ${ }^{3,18}$, consumption of calories after 8:00PM, increased fast food consumption, and shorter sleep duration ${ }^{3}$. 
Late sleepers had a higher caloric intake after 8:00PM compared to those who did not sleep as late, but not higher total daily caloric intake ${ }^{3,32}$. There were correlations found between higher caloric intake after 8:00PM and a higher total daily caloric intake, shorter sleep duration, and later sleep timing ${ }^{3}$. These interactions between nighttime eating, higher total caloric intake and problematic sleep patterns in middle aged individuals, highlighted the importance to investigate this association in college-aged students.

Reid and Baron have found such novel associations related to sleep patterns that they examined nighttime eating based on closeness of consumption to sleep onset and total daily caloric intake, rather than using meal times ${ }^{33}$. Sleep timing was measured by utilizing wrist actigraphy data ${ }^{33}$. Eating closer to sleep onset was found to be associated with higher total daily caloric intake ${ }^{3,33}$, this strengthens their previous findings that nighttime consumption and higher total caloric intake are associated in middle aged adults. Unfortunately, physical activity was not controlled for in either study, which impacts sleep patterns and calorie intake ${ }^{3,33}$. When examining adolescents (9 to 16-year-olds), Golley found correlations between sleep timing, diet quality, and BMI z-score ${ }^{18}$. These correlations were found with or without controlling for physical activity, energy intake, and sleep duration ${ }^{18}$.

\section{Nighttime eating and MetS:}

Due to high rates of overweight/obesity and MetS the college-aged population is at risk for developing chronic diseases in adulthood, including diabetes mellitus and cardiovascular risk ${ }^{27}$. Being either overweight and obesity 
increases the number of MetS criteria in college age men and women ${ }^{27}$. MetS is a group of disorders that puts one at risk for chronic disease, including cardiovascular disease. Criteria for MetS includes having three or more of the following risk factors: elevated abdominal obesity measured in waist circumference, blood lipid panel (TAG, HDL), blood pressure, and insulin resistance in blood glucose levels ${ }^{27}$.

One study examined MetS in three colleges located in various regions in the United States ${ }^{27}$. It was found that $9.9-12 \%$ men and 3-6\% women had three MetS risk factors, ${ }^{26,27}$, and $77 \%$ of the college-aged students had one criterion of MetS ${ }^{27}$. Lower physical activity was associated with an increased risk for being over-fat, having increased abdominal obesity, and meeting the criteria for the definition of MetS in these college students ${ }^{26}$. To our knowledge there has been no research specially examining nighttime eating and MetS in the college aged population, making this is a novel association. 
APPENDIX B: Methods timeline

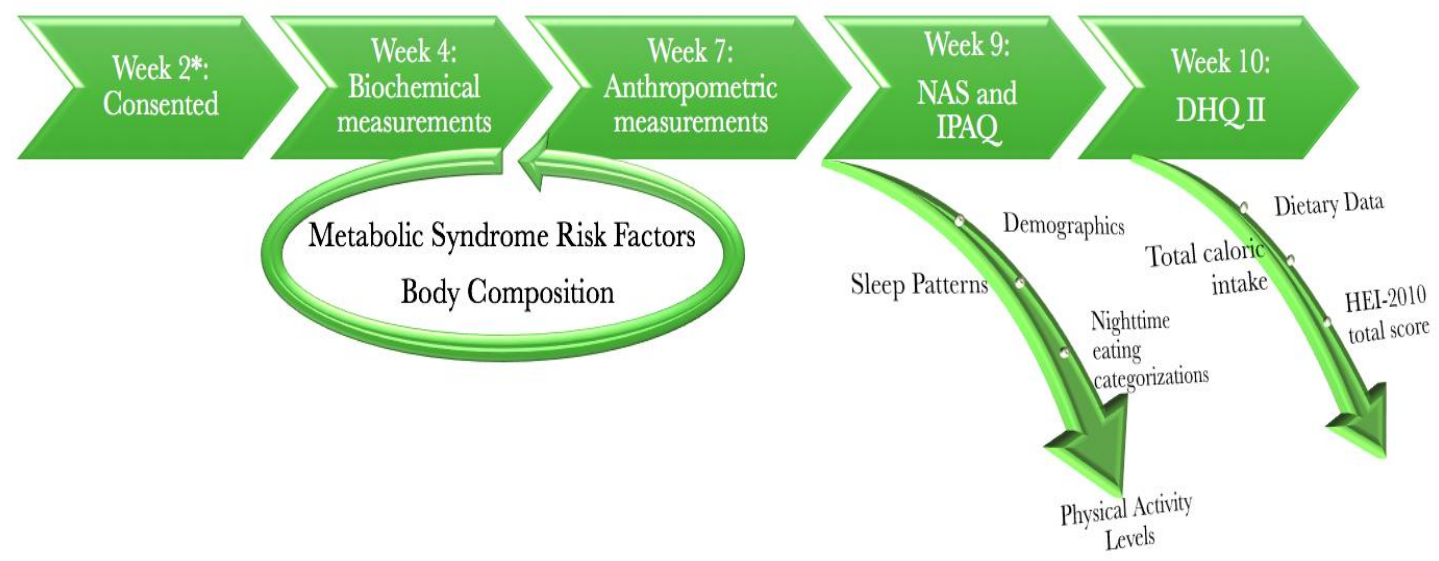

*Week number correlates to university semester schedule. 


\section{APPENDIX C: Consent Forms}

Consent Form Valid 12/15/2015-1/7/2017

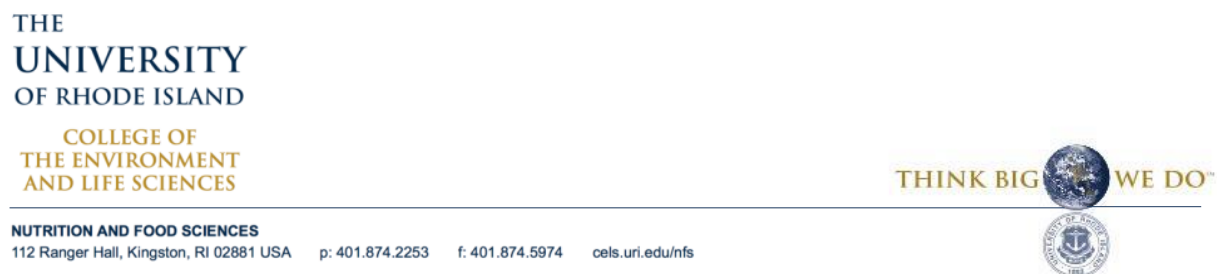

Title of Project: Nutrition Assessment Secondary Data Analysis

\section{CONSENT TO PARTICIPATE IN RESEARCH}

You are invited to take part in a research project described below. Students enrolled in NFS 210 and NFS 443 currently have anthropometric and biochemical assessments and complete dietary assessment as part of their coursework. These assessments are used for classroom assignments. We are asking you to give us permission to use these data for research. In addition, we are asking you to complete a few additional demographic and health related behavior questions. The purposes of the research is to validate assessment methodologies and to investigate the relationship between anthropometric, biochemical, and dietary variables that are related to chronic disease risk. If you have questions you may contact Geoffrey Greene, the person mainly responsible for this study at 874-4028 or email him at gwg@uri.edu.

Description of the Project:

The purpose of the study is to use nutrition assessment data for research to help us understand the relationship between diet and disease risk in college students.

My Participation

You must sign this informed consent form for the data collected as part of this class to be used for research, and must complete the additional brief online questionnaire.

What will be done:

If you take part in this study, your information will be entered into a database and stored on a secured server. The security measures in place to protect this database meet or exceed benchmarks set by the University of Rhode Island and the Center for Internet Security. Your data will be identified by code number only and only authorized study personnel will be able to access it. Once all data have been entered and verified, the link between code number and identifying data will be destroyed. All data analysis will be conducted by code number only. Assessments that we will be using are listed below (these are collected as part of your class and the additional brief demographic and health behavior questionnaire):
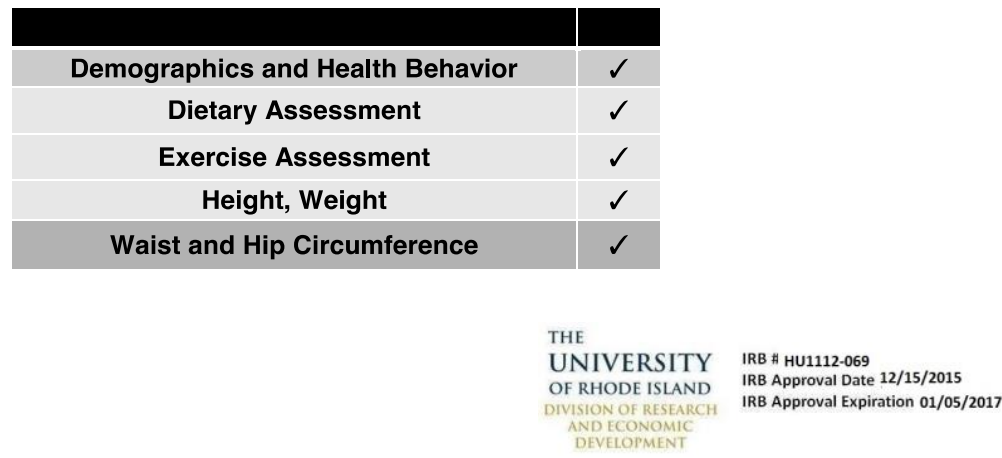


\section{\begin{tabular}{|c|c|}
\hline $\begin{array}{c}\text { Air Displacement Plethysmography } \\
\text { (BodPod) }\end{array}$ & $\checkmark$ \\
\hline $\begin{array}{c}\text { Sonographic Measurement of the Heel } \\
\text { (bone density) }\end{array}$ & $\checkmark$ \\
\hline $\begin{array}{c}\text { Standard Blood Tests (TG, HDL, LDL, Total } \\
\text { Cholesterol, Glucose) }\end{array}$ & $\checkmark$ \\
\hline
\end{tabular}}

Risks or discomfort:

The risks are minimal. The only risks would be loss of confidentiality and that will be minimized as described below.

Benefits of this study:

You will not receive any direct benefit. Allowing us to use your data and filling out the brief questionnaire will help us with research to better understand the relationship between diet and chronic disease in college students.

\section{Confidentiality:}

Your part in this study is confidential. None of the information will identify you name. We will keep all consent forms in a locked cabinet in Room 146 Fogarty for five years. All information collected for the class will be identified by code numbers and will not include any link to your name. This information will be confidential.

Decision to quit at any time:

You have been given the opportunity to decide whether or not to participate in this study. Your decision to participate will not affect your grade in the class or your relationship with your class instructor. Your instructor will not know who is participating in this study. You have the right to stop participating at any time, but once data have been entered and verified and the link between participant and code has been destroyed, we will not be able to remove your data.

Rights and Complaints:

If you are not satisfied with the way this study is performed, you may discuss your complaints with Geoffrey Greene (401-874-4028) anonymously, if you choose. In addition, if you have questions about your rights as a research participant, you may contact the Office of Research Integrity, 70 Lower College Road, Suite 2, University of Rhode Island, Kingston, RI, telephone: (401) 874-4328.

You have read this Consent Form. Your questions have been answered. Your signature on this form means that you understand the information and you agree to participate in the study. Please note that you must be at least 18 years of age in order to participate.

Print Your Name:

$\overline{\text { Signature of Participant }} \overline{\text { Date }} \quad \overline{\text { Signature of Researcher }}$

Please sign both consent forms, keeping one for yourself

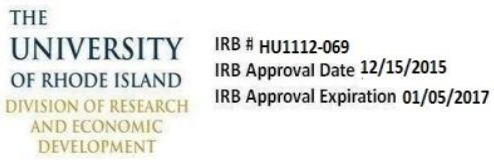


Consent Form Valid: 12/19/2016-12/19/2017

\author{
THE \\ UNIVERSITY \\ OF RHODE ISLAND
}

COLLEGE OF
HEALTH SCIENCES
$\begin{aligned} & \text { DEPARTMENT OF NUTRITION AND FOOD SCIENCES } \\ & 125 \text { Fogarty Hall, Kingston, RI 02881 USA } \quad \text { p: } 401.874 .2253\end{aligned} \quad$ f: $401.874 .5974 \quad$ web.uri.edu/nfs

Title of Project: Nutrition Assessment Secondary Data Analysis

INFORMED CONSENT TO PARTICIPATE IN RESEARCH

You are invited to take part in a research project described below. Students enrolled in NFS 210 and NFS 443 currently have anthropometric and biochemical assessments and complete dietary assessment as part of their coursework. These assessments are used for classroom assignments. We are asking you to give us permission to use these data for research. In addition, we are asking you to complete a few additional demographic and dietary questions. The purposes of the research is to validate assessment methodologies and to investigate the relationship between anthropometric, biochemical, and dietary variables that are related to chronic disease risk. If you have questions you may contact the Geoffrey Greene, the person mainly responsible for this study at 874-4028 or email him at gwg@uri.edu.

Description of the Project:

The purpose of the study is to use nutrition assessment data for research to help us understand the relationship between diet and disease risk in college students.

\title{
My Participation
}

You must sign this informed consent form for the data collected as part of this class to be used for research, and must complete the additional brief questionnaire.

What will be done:

If you take part in this study, your information entered into a password protected computer. Your data will be identified by code number only. Once all data have been entered and verified, the link between code number and identifying data will be destroyed. All data analysis will be conducted by code number only. Assessments that we will be using are listed below (these are collected as part of your class and the additional brief demographic questionnaire):

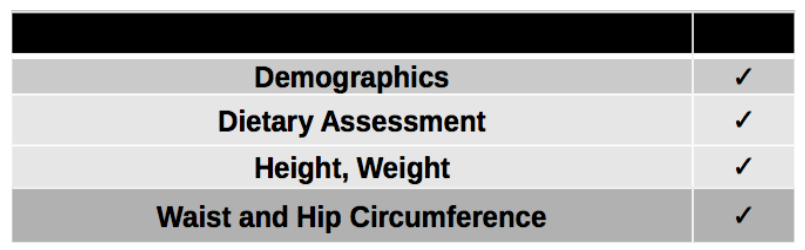




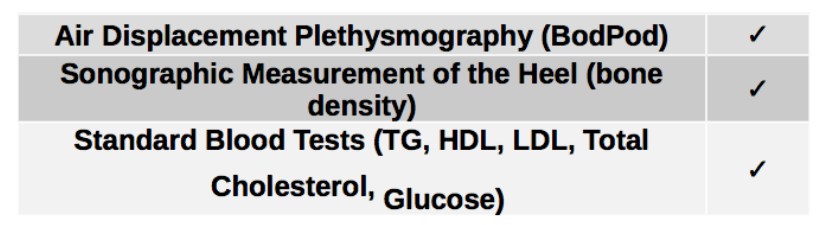

Risks or discomfort:

The risks are minimal. The only risks would be loss of confidentiality and that will be minimized as described below.

Benefits of this study:

You will not receive any direct benefit. Allowing us to use your data and filling out the brief questionnaire will help us with research to better understand the relationship between diet and chronic disease in college students.

Confidentiality:

Your part in this study is confidential. None of the information will identify you name. We will keep all consent forms in a locked cabinet in Room 307 Ranger for five years. All information collected for the class will be identified by code numbers and will not include any link to your name. This information will be confidential.

Decision to quit at any time:

Your have been given the opportunity to decide whether or not to participate in this study. Your decision to participate will not affect your grade in the class or your relationship with your class instructor. Your instructor will not know who is participating in this study. You have the right to stop participating at any time, but once data have been entered and verified and the link between participant and code has been destroyed, we will not be able to remove your data.

Rights and Complaints:

If you are not satisfied with the way this study is performed, you may discuss your complaints with Geoffrey Greene (401-874-4028) anonymously, if you choose. In addition, if you have questions about your rights as a research participant, you may contact the Office of Research Integrity, 70 Lower College Road, Suite 2, University of Rhode Island, Kingston, RI, telephone: (401) 874-4328.

You have read this Consent Form. Your questions have been answered. Your signature on this form means that you understand the information and you agree to participate in the study. Please note that you must be at least 18 years of age in order to participate.

Print Your Name:

$\overline{\text { Signature of Participant }} \overline{\text { Date }} \quad \overline{\text { Signature of Researcher }}$

Please sign both consent forms, keeping one for yourself 
APPENDIX D: Nutrition Assessment Survey

\section{NAS STARTS}

1. What is your age?

Less than 18 years

18 years

19 years

20 years

21 years

22 years

23 years

24 years

25 years

26 years

27 years

28 years

29 years

30 years

31 years

32 years

33 years

34 years

35 years

36 years

37 years

38 years

39 years

40 years

41 years

42 years

43 years

44 years

45 years

46 years

47 years

48 years

49 years

50 years

51 years

52 years

53 years

54 years

55 years

56 years

57 years

58 years

59 years

60 or more years 
2. What is your gender?

Male, female, choose not to answer

3. Which one of the following best applies to you?

- White

- Black or African American

- Hispanic/Latino

- Asian

- Native Hawaiian or other Pacific Islander

- American Indian or Alaskan Native

- Mixed

- Other (please specify):

- Choose not to answer

4. What is your year in school?

Freshman, Sophomore, Junior, Senior, Graduate

5. What is your current major?

- Agricultural Sciences

- Biological Sciences

- Business/Communication

- Education

- Exercise Science/Kinesiology

- Fine Arts/Humanities

- Health/Nursing

- Nutrition

- Social Sciences

- Undeclared

- Graduate Student

- Other (please specify):

- Choose not to answer

6 . Place of residence during the academic year?

- On campus

- Off campus

- Choose not to answer 
7. Green Eating is: Eating locally grown foods, limited amounts of processed/fast foods, eating meatless meals at least one day per week, choosing organic foods as much as possible, and only taking what you plan on eating.

Are you a green eater?

- No, and I do not intend to start within the next 6 months

- No, but I am thinking about becoming a green eater within the next 6 months

- No, but I am planning on becoming a green eater within the next 30 days

- Yes, I am a green eater and have been for less than 6 months

- Yes, I am a green eater and have been doing so for 6 months or more

- I choose not to answer

8. Which of the following best describes the MAJORITY of your meals during the academic year?

- I eat meals prepared at home.

- I purchase frozen or ready-to-eat meals

- I eat at dining halls/restaurants

- I get fast food/take-out

- Choose not to answer

9. Do you have a campus meal plan?

- Yes

- No

- Choose not to answer

10. What is your usual rate of eating?

$\begin{array}{llllll}\begin{array}{l}\text { Very } \\ \text { slow }\end{array} & \text { Slow } & \text { Medium } & \text { Fast } & \text { Very fast } & \begin{array}{c}\text { Choose not to } \\ \text { answer }\end{array} \\ 1 & 2 & 3 & 4 & 5 & 6\end{array}$

11. Do you experience abdominal discomfort such as cramping, bloating, or excess gas? (this refers to gastrointestinal discomfort, NOT menstrual discomfort)

- Never or very seldom

- Seldom, less than once per month

- Occasionally, a few times per month

- Fairly often, once or twice per week

- Very often, several times per week or daily

- Choose not to answer 
12. If you experience abdominal discomfort, how severe is it?

- I do not experience abdominal discomfort

- Very mild -not very noticeable

- Moderate - noticeable but not too bad

- Somewhat uncomfortable - it's kind of bad, but manageable

- Very uncomfortable - I cannot carry out my normal activities

- Choose not to answer

13. Please select the answer that BEST describes your usual behavior.

\begin{tabular}{|c|c|c|c|c|c|c|}
\hline & $\begin{array}{l}\text { Barely } \\
\text { ever to } \\
\text { never }\end{array}$ & $\begin{array}{l}\text { Rarely } \\
(25 \%)\end{array}$ & $\begin{array}{c}\text { Sometimes } \\
(50 \%)\end{array}$ & $\begin{array}{l}\text { Often } \\
(75 \%)\end{array}$ & $\begin{array}{l}\text { Almost } \\
\text { always }\end{array}$ & $\begin{array}{l}\text { Choose } \\
\text { Not to } \\
\text { Answer }\end{array}$ \\
\hline $\begin{array}{l}\text { - Locally grown } \\
\text { foods are grown } \\
\text { within } 100 \text { miles } \\
\text { of your location. } \\
\text { Based on this, } \\
\text { how often do you } \\
\text { eat locally grown } \\
\text { foods? }\end{array}$ & 0 & $\mathrm{o}$ & $\mathrm{O}$ & 0 & $\mathrm{O}$ & \\
\hline $\begin{array}{l}\text { - When in season, } \\
\text { how often do you } \\
\text { shop at farmer's } \\
\text { markets? }\end{array}$ & o & o & $\mathrm{O}$ & o & o & \\
\hline $\begin{array}{l}\text { - How often do } \\
\text { you choose foods } \\
\text { that are labeled } \\
\text { certified organic? }\end{array}$ & $\mathrm{o}$ & $\mathrm{o}$ & o & 0 & o & \\
\hline $\begin{array}{l}\text { - How often do } \\
\text { you select meats, } \\
\text { poultry, and dairy } \\
\text { products that are } \\
\text { raised without } \\
\text { antibiotics or } \\
\text { hormones? }\end{array}$ & $\mathrm{O}$ & $\mathrm{o}$ & $\mathrm{o}$ & o & 0 & \\
\hline $\begin{array}{l}\text { - How often do } \\
\text { you select food or } \\
\text { beverages that are } \\
\text { labeled fair trade } \\
\text { certified? }\end{array}$ & $\mathrm{O}$ & $\mathrm{o}$ & $\mathrm{O}$ & $\mathrm{o}$ & $\mathrm{O}$ & \\
\hline $\begin{array}{l}\text { - How often do } \\
\text { you buy meat or } \\
\text { poultry products } \\
\text { labeled "free } \\
\text { range" or "cage } \\
\text { free"? }\end{array}$ & $\mathrm{o}$ & $\mathrm{O}$ & $\mathrm{O}$ & $\mathrm{O}$ & $\mathrm{o}$ & \\
\hline
\end{tabular}


14. Have you smoked at least 100 cigarettes in your entire life? (NOTE: 5 packs $=$ 100 cigarettes)

- Yes

- No

- I choose not to answer

15. Do you NOW smoke cigarettes every day, some days, or not at all?

- Every day

- Some days

- Not at all

- I choose not to answer

16. What would you like to weigh in pounds? Put CNA if you choose not to answer

17. How would YOU describe your current weight?

- Very underweight

- Slightly underweight

- About the right weight

- Slightly overweight

- Very overweight

- I choose not to answer

18. How do you feel about your current weight?

- I am happy with my current weight

- I don't care about my current weight

- I am upset about my current weight

- Choose not to answer

19. On average, how many hours of sleep do you get in a 24-hour period? Think about the time you actually spent sleeping or napping, not just the amount of sleep you think you should get. How many hours do you usually get each day and night?

- 1 hour or less

- 2 hours

- 3 hours

- 4 hours

- 5 hours

- 6 hours

- 7 hours

- 8 hours

- 9 hours

- 10 hours or more

- Choose not to answer

20. Are you often sleepy during the day? (yes or no - choose not to answer) 
21. Do you frequently wake up during the time you are asleep? (yes or no - choose not to answer

22. How would you evaluate the quality of your sleep? (not impaired, moderately impaired, severely impaired - choose not to answer) What is your usual bed time?

- Before 9:00 PM

- 9:00 PM

- 10:00 PM

- 11:00 PM

- 12:00 AM

- 1:00 AM

- 2:00 AM

- 3:00 AM

- 4:00 AM

- After 4:00 AM

How many hours before bed do you usually eat your last meal or snack?

- $<1$ hour

- 1 hour

- 2 hour

- 3 hour

- 4 hour

- 5 hour

- 6 hour

- $>6$ hours

How many days a week do you usually eat breakfast?

- 0

- 1

- 2

- 3

- 4

- 5

- 6

- 7

- Choose not to answer 
23. Stress management includes regular relaxation and physical activity, talking with others and/or making time for social activities.

Do you effectively practice stress management in your daily life?

- No, and I do NOT intend to in the next 6 months

- No, but I intend to in the in the next 6 months

- No, but I intend to in the next 30 days

- Yes, but I have been for LESS than 6 months

- Yes and I have been for MORE than 6 months

- I choose not to answer

\section{END NAS}


APPENDIX E: International Physical Activity Questionnaire

\title{
INTERNATIONAL PHYSICAL ACTIVITY QUESTIONNAIRE (August 2002) \\ SHORT LAST 7 DAYS SELF-ADMINISTERED FORMAT
}

\author{
FOR USE WITH YOUNG AND MIDDLE-AGED ADULTS (15-69 years)
}

\begin{abstract}
The International Physical Activity Questionnaires (IPAQ) comprises a set of 4 questionnaires. Long ( 5 activity domains asked independently) and short (4 generic items) versions for use by either telephone or self-administered methods are available. The purpose of the questionnaires is to provide common instruments that can be used to obtain internationally comparable data on health-related physical activity.
\end{abstract}

\section{Background on IPAQ}

The development of an international measure for physical activity commenced in Geneva in 1998 and was followed by extensive reliability and validity testing undertaken across 12 countries (14 sites) during 2000 . The final results suggest that these measures have acceptable measurement properties for use in many settings and in different languages, and are suitable for national population-based prevalence studies of participation in physical activity.

Using IPAQ

Use of the IPAQ instruments for monitoring and research purposes is encouraged. It is recommended that no changes be made to the order or wording of the questions as this will affect the psychometric properties of the instruments.

Translation from English and Cultural Adaptation

Translation from English is supported to facilitate worldwide use of IPAQ. Information on the availability of IPAQ in different languages can be obtained at www.ipaq.ki.se. If a new translation is undertaken we highly recommend using the prescribed back translation methods available on the IPAQ website. If possible please consider making your translated version of IPAQ available to others by contributing it to the IPAQ website. Further details on translation and cultural adaptation can be downloaded from the website.

\section{Further Developments of IPAQ}

International collaboration on IPAQ is on-going and an International Physical Activity Prevalence Study is in progress. For further information see the IPAQ website.

More Information

More detailed information on the IPAQ process and the research methods used in the development of IPAQ instruments is available at www.ipaq.ki.se and Booth, M.L. (2000). Assessment of Physical Activity: An International Perspective. Research Quarterly for Exercise and Sport, 71 (2): s114-20. Other scientific publications and presentations on the use of IPAQ are summarized on the website. 


\section{INTERNATIONAL PHYSICAL ACTIVITY QUESTIONNAIRE}

We are interested in finding out about the kinds of physical activities that people do as part of their everyday lives. The questions will ask you about the time you spent being physically active in the last 7 days. Please answer each question even if you do not consider yourself to be an active person. Please think about the activities you do at work, as part of your house and yard work, to get from place to place, and in your spare time for recreation, exercise or sport.

Think about all the vigorous activities that you did in the last 7 days. Vigorous physical activities refer to activities that take hard physical effort and make you breathe much harder than normal. Think only about those physical activities that you did for at least 10 minutes at a time.

1. During the last $\mathbf{7}$ days, on how many days did you do vigorous physical activities like heavy lifting, digging, aerobics, or fast bicycling?

days per week

No vigorous physical activities $\longrightarrow$ Skip to question 3

2. How much time did you usually spend doing vigorous physical activities on one of those days?

hours per day

minutes per day

Don't know/Not sure

Think about all the moderate activities that you did in the last 7 days. Moderate activities refer to activities that take moderate physical effort and make you breathe somewhat harder than normal. Think only about those physical activities that you did for at least 10 minutes at a time.

3. During the last $\mathbf{7}$ days, on how many days did you do moderate physical activities like carrying light loads, bicycling at a regular pace, or doubles tennis? Do not include walking.

days per week

No moderate physical activities $\longrightarrow$ Skip to question 5

SHORT LAST 7 DAYS SELF-ADMINISTERED version of the IPAQ. Revised August 2002. 
4. How much time did you usually spend doing moderate physical activities on one of those days?

hours per day

minutes per day

Don't know/Not sure

Think about the time you spent walking in the last 7 days. This includes at work and at home, walking to travel from place to place, and any other walking that you have done solely for recreation, sport, exercise, or leisure.

5. During the last $\mathbf{7}$ days, on how many days did you walk for at least 10 minutes at a time?

days per week

No walking $\longrightarrow$ Skip to question 7

6. How much time did you usually spend walking on one of those days?

hours per day

minutes per day

Don't know/Not sure

The last question is about the time you spent sitting on weekdays during the last 7 days. Include time spent at work, at home, while doing course work and during leisure time. This may include time spent sitting at a desk, visiting friends, reading, or sitting or lying down to watch television.

7. During the last $\mathbf{7}$ days, how much time did you spend sitting on a week day?

hours per day

minutes per day

Don't know/Not sure

This is the end of the questionnaire, thank you for participating.

SHORT LAST 7 DAYS SELF-ADMINISTERED version of the IPAQ. Revised August 2002 


\section{APPENDIX F: Dietary History Questionnaire II}

A. Further detailed information can be found on the DHQ II at: https://epi.grants.cancer.gov/dhq2/about/ 
APPENDIX G: Biochemical measurement document

\section{Blood Lipids, Glucose, \& Blood Pressure Results}

Name:

Student ID Number:

Your Results

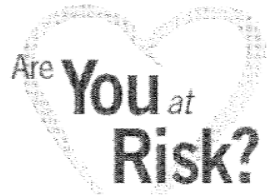

Blood Pressure

- Desirable: $<120 / 80 \mathrm{mmHg}$

- Borderline high: $\geq 130 / 85 \mathrm{mmHg}$

- High: $\geq 140 / 90 \mathrm{mmHg}$

Total Cholesterol

- Desirable: $<200 \mathrm{mg} / \mathrm{dL}$

- Borderline: $200-239 \mathrm{mg} / \mathrm{dL}$

- High: $\geq 240 \mathrm{mg} / \mathrm{dl}$

HDL Cholesterol

- Low: < 40mg/dL

- High: $\geq 60 \mathrm{mg} / \mathrm{dL}$

LDL Cholesterol

- Optimal: $<100 \mathrm{mg} / \mathrm{dL}$

- Near optimal/above optimal: $100-129 \mathrm{mg} / \mathrm{dL}$

- Borderline high: $130-159 \mathrm{mg} / \mathrm{dL}$

- High: $160-189 \mathrm{mg} / \mathrm{dL}$

- Very high: $\geq 190 \mathrm{mg} / \mathrm{dL}$

Triglycerides

- Normal: $<150 \mathrm{mg} / \mathrm{dL}$

- Borderline high: 150-199 mg/dL

- High: $200-499 \mathrm{mg} / \mathrm{dL}$

- Very high: $\geq 500 \mathrm{mg} / \mathrm{dL}$

Glucose

- Normal fasting glucose: $<100 \mathrm{mg} / \mathrm{dL}$

- Impaired fasting glucase: $100-126 \mathrm{mg} / \mathrm{dL}$

- High fasting glucose: $\geq 126 \mathrm{mg} / \mathrm{dL}$

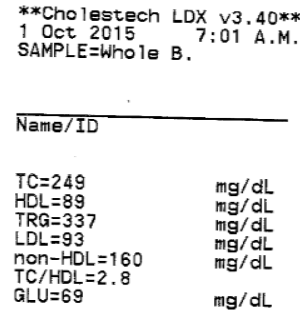

1 Oct 2015 LDX 7:40*

TRG $=337$

hon-HDL $=160$

$G L U=69$

$m g / d L$

\begin{tabular}{|c|c|}
\hline BP 1 & \\
\hline BP 2 & \\
\hline BP 3 (if necessary) & \\
\hline BP 4 (if necessary) & \\
\hline
\end{tabular}

National Cholesterol Education Program Adult Treatment Panel III Guidelines, American Diabetes Association 


\title{
APPENDIX H: Anthropometric instructional document
}

\author{
NFS 210 Applied General Nutrition \\ Instructions for Preparation for Anthropometric and Bone Density Measurements
}

Name

Lab Section

Appointment Day/Time

Come to Fogarty Hall room 105 at your scheduled time for the following measurements and tests.

Height

Weight

Waist and hip circumference

Body composition - BOD POD

Bone density - Bone Ultrasonometer

Instructions for Preparation

Do not eat or exercise within 2 hours prior to the appointment. Come well-hydrated but don't drink large amounts of fluid within 2 hours prior to the appointment.

\section{Specific instructions for preparation for BOD POD testing}

The surface area of clothing and hair can have a significant impact on volume measurements. For accurate results, it is important that you wear minimal, form-fitting clothing. If possible, wear the following recommended clothing under your outer clothing to cut down on time needed for changing.

For MALES, recommended clothing is either:

(1) Form-fitting Speedo ${ }^{\circledR}$ or other Lycra ${ }^{\circledR} /$ spandex-type swim suit; or

(2) Single-layer compression shorts (only shorts without padding)

For FEMALES, recommended clothing is either:

(1) Form-fitting Speedo ${ }^{\circledR}$ or other Lycra ${ }^{\circledR} /$ spandex-type swim suit; or

(2) Single-layer compression shorts (only shorts without padding) and single-layer (not padded) jog bra.

You should not wear any other article of clothing except for what is specified above (i.e. jewelry, socks, eyeglasses, etc.).

During the volume measurements that are part of a body composition test, you must wear a swim cap (this will be provided). It is also important that all of your hair is in the swim cap and any air pockets under the cap are pushed out. Even people with very little hair should wear the swim cap during testing. Deviations from this protocol will likely result in invalid results.

If necessary, prior to a body composition test, you should use the restroom.

Cell phones should not be used while the BOD POD is in operation.

If you have any questions or concerns about any of these procedures, discuss it with your instructor.

If you miss your appointment without a valid university-approved excuse, you will lose lab points. 
APPENDIX I: Anthropometric assessment document

\section{NFS 210 Applied General Nutrition Anthropometric and Bone Density Measurements}

Name:

Student ID Number

Record your personal bone density T-scores and anthropometric information on this sheet. You will need this information to complete assignments in lab 6 so keep this paper in a safe place.

Bone Ultrasonometer Test Results

Right Heel T-Score:

Right Heel BMD:

Anthropometric Information

Height: $\mathrm{cm}$

Weight: $\mathrm{kg}$

1 inch $=2.54 \mathrm{~cm}$

1 pound $=0.45 \mathrm{~kg}$

Waist Circumference: $\mathrm{cm}$

Hip Circumference: $\mathrm{cm}$

Body Fat Percentage

BOD POD: $\%$

Body Mass Index (BMI)

$\mathrm{BMI}=\frac{\text { Weight }(\mathrm{kg})}{\text { Height }(\mathrm{m})^{2}}$

BMl: $\mathrm{kg} / \mathrm{m}^{2}$

Weight (lb) $\times 703$ Height (in) ${ }^{2}$ 


\title{
APPENDIX J: HEI-2010 Total Score Export Information
}

\author{
Calculation of the Healthy Eating Index-2010 component and total scores based on data from the Die \\ History Questionnaire (DHQ) and Diet*Calc output
}

This SAS program, along with the two additional required SAS macros, can be used to calculate Healthy Eating Index (HEI)-2010 scores from data collected using the DHQII in conjunction with the most recent Diet*Calc database, released January 2015, that includes values from the Food Patterns Equivalents Database (FPED).

This program calculates $\mathrm{HEI}-2010$ component and total scores for each individual, and must be run in SAS version 9.4 or higher.

The total score and the 12 components of the HEI-2010 are:

Total HEI-2010 Score (HEI2010_TOTAL_SCORE)

Total Fruit (HEI2010_COMP_TOT_FRUIT)

Whole Fruit (HEI2010_COMP_WHOLE_FRUIT)

Total Vegetables (HEI2010_COMP_TOT_VEG)

Greens and Beans (HEI2010_COMP_DRK_GRN_BEAN)

Whole Grains (HEI2010_COMP_WHOLE_GRAIN)

Dairy (HEI2010_COMP_TOT_DAIRY)

Total Protein Foods (HEI2010_COMP_TOT_MEAT_PRO_FD)

Seafood and Plant Proteins (HEI2010_COMP_SEA_FD_PLANT_PRO)

Fatty Acids (HEI2010_COMP_FATTY_ACID)

Refined Grains (HEI2010_COMP_REFINED_GRAIN)

Sodium (HEI2010_COMP_SODIUM)

Empty Calories (HEI2010_COMP_EMPTY_KCAL)

Additionally, the output contains the density variables used to create the component scores:

DENSITY OF FPED TOTAL VEGETABLES/1000 KCAL (TOT_VEG_FPED_DEN)

DENSITY OF FPED DARK GREEN VEG AND BEANS/1000 KCAL (DRK_GRN_BEAN_FPED_DEN)

DENSITY OF FPED TOTAL FRUIT/1000 KCAL (TOT_FRUIT_FPED_DEN)

DENSITY OF FPED WHOLE FRUIT PER/1000 KCAL (WHOLE_FRUIT_FPED_DEN)

DENSITY OF FPED REFINED GRAINS/1000 KCAL (REFINED_GRAIN_FPED_DEN)

DENSITY OF FPED WHOLE GRAIN/1000 KCAL (WHOLE_GRAIN_FPED_DEN)

DENSITY OF FPED DAIRY/1000 KCAL (TOT_DAIRY_FPED_DEN)

DENSITY OF FPED TOTAL MEAT/PROTEIN/1000 KCAL (TOT_MEAT_PRO_FD_FPED_DEN)

DENSTIY OF FPED SEAFOOD AND PLANT PROTEIN/1000 KCAL (SEA_FD_PLANT_PRO_FPED_DEN)

FATTY ACID RATIO (FATTY_ACID RATIO)

DENSITY OF SODIUM/1000 KCAL (SODIUM_DEN)

PERCENT EMPTY KCAL FROM SOLID FAT, ADDED SUGAR, AND ALCOHOL (PCT_EMPTY_KCAL)

Some of these components come directly from Diet*Calc output but others must be created.

The list below includes FPED and other variables available from Diet*Calc output that are used directly or as part of a calculation to create the HEl components listed above:

Total Fruit (FPED_F_TOTAL_CP_EQUIV_USDA) in cup equivalents 
Whole Fruit (FPED_F_CITMLB_CP_EQUIV_USDA + FPED_F_OTHER_CP_EQUIV_USDA) in cup equivalents Total Vegetables (FPED_V_TOTAL_CP_EQUIV_USDA) in cup equivalents Dark Green Vegetables (FPED_V_DRKGR_CP_EQUIV_USDA) in cup equivalents Legumes (FPED_V_LEGUMES_CP_EQUIV_USDA) in cup equivalents Whole Grains (FPED_G_WHOLE_OZ_EQUIV_USDA) in ounce equivalents Refined Grains (FPED_G_REFINED_OZ_EQUIV_USDA) in ounce equivalents Total Milk (FPED_D_TOTAL_CP_EQUIV_USDA) in cup equivalents

Meat, Poultry, Fish (FPED_PF_MPS_TOTAL_OZ_EQUIV_USDA) in ounce equivalents Eggs (FPED_PF_EGGS_OZ_EQUIV_USDA) in ounce equivalents

Nut and Seeds (FPED_PF_NUTSDS_OZ_EQUIV_USDA) in ounce equivalents Soybean Products (FPED_PF_SOY_OZ_EQUIV_USDA) in ounce equivalents High-fat Fish (FPED_PF_SEAFD_HI_OZ_EQUIV_USDA) in ounce equivalents Low-fat Fish (FPED_PF_SEAFD_LOW_OZ_EQUIV_USDA) in ounce equivalents Discretionary Solid Fat (FPED_SOLID_FATS_G_EQUIV_USDA) in grams Added Sugars (FPED_ADD_SUGARS_TSP_EQUIV_USDA) in teaspoon equivalents Energy (ENERGY_KCAL_USDA) in kcal Saturated Fat (TOTAL_SAT_FA_G_USDA) in grams Monounsaturated Fat (TOTAL_MONOUNSAT_FA_G_USDA) in grams Polyunsaturated Fat (TOTAL_POLYUNSAT_FA_G_USDA) in grams

Sodium (SODIUM_MG_USDA) in milligrams

Alcohol (ALCOHOL_G_USDA) in grams

This SAS program carries out 5 steps:

1. Reads in the original Diet*Calc results in two parts: First, it reads in the variable names, then it reads in the variable values.

Note: This two-part process is necessary because some of the variable names in the Diet*Calc results file are not compatible with SAS variable name requirements.

2. Creates six required variables: MONOPOLY, FPED_WHOLE_FRT, FPED_V_TOTAL, ALLMEAT, SEAPLANT and EMPTYCAL10.

Calculation note for MONOPOLY: Monounsaturated fatty acids and polyunsaturated fatty acids are summed together (TOTAL_MONOUNSAT_FA_G_USDA + TOTAL_POLYUNSAT_FA_G_USDA = MONOPOLY). To estimate the fatty acid ratio of unsaturated fatty acids to saturated fatty acids, this value is then divided by saturated fatty acids (MONOPOLY/TOTAL_SAT_FA_G_USDA).

Calculation note for FPED_WHOLE_FRT and FPED_V_TOTAL: Citrus, Melons and Berries are summed with Other Fruits to generate the value for Whole Fruit. The total vegetable intake variable is renamed to have fewer characters (required by SAS) to allow the macros to run successfully.

Calculation note for ALLMEAT and SEAPLANT: ALLMEAT sums together all animal and plant proteins, including meat, poultry, fish, eggs, nuts, seeds, and soy (FPED_PF_MPS_TOTAL_OZ_EQUIV_USDA + FPED_PF_EGGS_OZ_EQUIV_USDA + FPED_PF_NUTSDS_OZ_EQUIV_USDA +

FPED_PF_SOY_OZ_EQUIV_USDA = ALLMEAT); while SEAPLANT sums together all fish and plant proteins, including fish, soy, nuts, and seeds (FPED_PF_SEAFD_HI_OZ_EQUIV_USDA + FPED_PF_SEAFD_LOW_OZ_EQUIV_USDA + 
FPED_PF_SOY_OZ_EQUIV_USDAFPED_PF_SOY OZ EQUIV_USDA +

FPED_PF_NUTSDS_OZ_EQUIV_USDA= SEAPLANT). An additional step is then required to determine how to include FPED_V_LEGUMES_CP_EQUIV_USDA in ALLMEAT and SEAPLANT (see Step 3). Please note that there are two versions of 'legumes' from the file. The correct variable to use is FPED_V_LEGUMES_CP_EQUIV_USDA (in cup equivalents). The other version,

FPED_PF_LEGUMES_OZ_EQUIV_USDA has different units (in ounce equivalents) not intended for the macro.

Calculation note for EMPTYCAL10: Empty Calories (EMPTYCAL10) is calculated using data on Discretionary Solid Fat (FPED_SOLID_FATS_G_EQUIV_USDA), Added Sugars

(FPED_ADD_SUGARS_TSP_EQUIV_USDA), and Alcohol (ALCOHOL_G_USDA). In the HEl-2010, energy

from alcohol is considered to be empty calories, but only when alcohol is consumed beyond moderate amounts. The least restrictive of the two levels defined as moderate drinking in the Dietary Guidelines, 2 drinks per day (converted to 28 grams of ethanol), was used to set the threshold for counting alcohol as empty calories. A value of 2150 calories was used to energy-adjust the alcohol threshold, based on the estimated median energy intake of adults. Because 28 grams ethanol/2150 calories equals 13 grams ethanol/1000 calories, only amounts greater than 13 grams of ethanol/1000 calories are counted towards Empty Calories.

3. Runs the macro to properly allocate the intakes of the FPED variable Legumes (FPED_V_LEGUMES_CP_EQUIV_USDA) to either Total Protein Foods and Seafood and Plant Proteins (ALLMEAT and SEAPLANT) or Total Vegetables and Greens and Beans (FPED_V_TOTAL and FPED_V_DRKGR_CP_EQUIV_USDA). The four resulting variables from this step, named LEGUME_ADDED_FPED_V_TOTAL, LEGUME_ADDED_BEANGRN, LEGUME_ADDED_ALLMEAT, and LEGUME_ADDED_SEAPLANT are all used in the next step.

Calculation notes for Total Protein Foods; Seafood and Plant Proteins; Total Vegetables; and Greens and Beans: Intake of the FPED variable, Legumes, counts toward meeting the standard for the Total Protein Foods (and Seafood and Plant Proteins) components first. Once the Total Protein Foods standard is met, any additional amount of Legumes counts toward the Total Vegetables and the Greens and Beans components. Units for FPED variable Legumes as well as for the HEl components Total Vegetables and Greens and Beans are in cup equivalents. However, the units for Total Protein Foods and Seafood and Plant Proteins are in ounce equivalents. Therefore, when Legumes are counted toward meeting the requirement for Total Protein Foods (and Seafood and Plant Proteins), the cup equivalents are converted to ounce equivalents. Once the Total Protein Foods standard is met, they are then converted back to cup equivalents and counted as Total Vegetables (and Greens and Beans).

Calculation note regarding conversion of cup equivalents to ounce equivalents: A one-fourth cup equivalent of Legumes is equal to a 1 ounce equivalent of Total Protein Foods and Seafood and Plant Proteins. Thus, the number of cup equivalents of Legumes is multiplied by 4 to convert to ounce equivalents of Total Protein Foods and Seafood and Plant Proteins.

5. Saves the results for each individual in a comma delimited text file with a name provided by the user that ends with: withhei.results.txt.

This code was written by Lisa Kahle of Information Management Services, Inc. 
APPENDIX K: HEI-2010 Scoring Guide

\begin{tabular}{|c|c|c|c|}
\hline HEI- $2010^{1}$ component & Maximum & Standard for maximum score & Standard for minimum score of zero \\
\hline \multicolumn{4}{|c|}{$\triangle$ Adequacy (higher score indicates higher consumption) } \\
\hline Total Fruit ${ }^{2}$ & 5 & $\geq 0.8$ cup equiv. $/ 1,000 \mathrm{kcal}^{10}$ & No fruit \\
\hline Whole Fruit $^{3}$ & 5 & $\geq 0.4$ cup equiv. $/ 1,000 \mathrm{kcal}$ & No whole fruit \\
\hline Total Vegetables ${ }^{4}$ & 5 & $\geq 1.1$ cup equiv. $/ 1,000 \mathrm{kcal}$ & No vegetables \\
\hline Greens and Beans ${ }^{4}$ & 5 & $\geq 0.2$ cup equiv. $/ 1,000 \mathrm{kcal}$ & No dark-green vegetables, beans, or peas \\
\hline Whole Grains & 10 & $\geq 1.5$ ounce equiv. $/ 1,000 \mathrm{kcal}$ & No whole grains \\
\hline Dairy $^{5}$ & 10 & $\geq 1.3$ cup equiv. $/ 1,000 \mathrm{kcal}$ & No dairy \\
\hline Total Protein Foods ${ }^{6}$ & 5 & $\geq 2.5$ ounce equiv. $/ 1,000 \mathrm{kcal}$ & No protein foods \\
\hline Seafood and Plant Proteins ${ }^{6,7}$ & 5 & $\geq 0.8$ ounce equiv. $/ 1,000 \mathrm{kcal}$ & No seafood or plant proteins \\
\hline Fatty Acids ${ }^{8}$ & 10 & $($ PUFAs + MUFAs) $/$ SFAs $\geq 2.5$ & (PUFAs + MUFAs) $/$ SFAs $\leq 1.2$ \\
\hline \multicolumn{4}{|c|}{$\nabla$ Moderation (higher score indicates lower consumption) } \\
\hline Refined Grains & 10 & $\leq 1.8$ ounce equiv. $/ 1,000 \mathrm{kcal}$ & $\geq 4.3$ ounce equiv. $/ 1,000 \mathrm{kcal}$ \\
\hline Sodium & 10 & $\leq 1.1 \mathrm{gram} / 1,000 \mathrm{kcal}$ & $\geq 2.0$ grams $/ 1,000 \mathrm{kcal}$ \\
\hline Empty Calories $^{9}$ & 20 & $\leq 19 \%$ of energy & $\geq 50 \%$ of energy \\
\hline \multicolumn{4}{|c|}{$\begin{array}{l}{ }^{1} \text { Intakes between the minimum and maximum standards are scored proportionately. } \\
{ }^{2} \text { Includes } 100 \% \text { fruit juice. } \\
{ }^{3} \text { Includes all forms except juice. } \\
{ }^{4} \text { Includes any beans and peas not counted as Total Protein Foods. } \\
5 \text { Includes all milk products, such as fluid milk, yogurt, and cheese, and fortified soy beverages. } \\
{ }^{6} \text { Beans and peas are included here (and not with vegetables) when the Total Protein Foods standard is otherwise not met. } \\
7{ }^{7} \text { Includes seafood, nuts, seeds, soy products (other than beverages) as well as beans and peas counted as Total Protein Foods. } \\
{ }^{8} \text { Ratio of poly- and monounsaturated fatty acids (PUFAs and MUFAs) to saturated fatty acids (SFAs). } \\
{ }^{9} \text { Calories from solid fats, alcohol, and added sugars; threshold for counting alcohol is }>13 \text { grams } / 1,000 \text { kcal. } \\
{ }^{10} \text { Equiv. = equivalent, kcal = kilocalories. }\end{array}$} \\
\hline
\end{tabular}


APPENDIX L: Table of Potential Pitfalls Identified in Thesis Proposal

\begin{tabular}{|c|c|}
\hline \multicolumn{2}{|c|}{ Potential Pitfalls of Study Outcomes and Solutions to Address Concerns } \\
\hline Pitfall & Solution \\
\hline $\begin{array}{l}\text { Total sample categorized as } \\
\text { nighttime eaters, defined as caloric } \\
\text { intake within } 4 \text { hours of sleep onset } \\
\text { or after } 8: 00 \mathrm{PM}^{3,5,32,33} \text {. }\end{array}$ & $\begin{array}{l}\text { Alter definition to only capture those consuming } \\
\text { calories within two or one hour(s) of sleep onset, } \\
\text { or examine the cutoff point as 9:00,10:00PM, or } \\
\text { later as needed, for nighttime eating } \\
\text { categorization. }\end{array}$ \\
\hline $\begin{array}{l}\text { Entire sample categorized as non- } \\
\text { nighttime eaters, defined as no } \\
\text { caloric intake within } 4 \text { hours of sleep } \\
\text { onset or after 8:00PM. }\end{array}$ & $\begin{array}{l}\text { Alter definition to capture those consuming } \\
\text { calories within five or six hours of sleep onset, or } \\
\text { examine the cutoff point as 8:00, 7:00PM, or } \\
\text { earlier as needed, for nighttime eating } \\
\text { categorization. }\end{array}$ \\
\hline $\begin{array}{l}\text { Accuracy of self-reported FFQ, the } \\
\text { DHQ }{ }^{38} \text {. }\end{array}$ & $\begin{array}{l}\text { The nutrition course material includes portion } \\
\text { estimation lessons, this population enrolled in this } \\
\text { general nutrition course has more background to } \\
\text { estimate portion sizes than a lay person. The DHQ } \\
\text { is not administered until the } 10^{\text {th }} \text { week of the } \\
\text { academic semester, therefore they have had } 10 \\
\text { weeks of exposure to general nutrition information } \\
\text { at a college level, and short term portion size } \\
\text { lessons have been shown to increase the accuracy } \\
\text { of college-aged students' portion size estimates }{ }^{7} \text {. } \\
\text { Measured variables (biochemical and body fat } \\
\text { percentage) would be more heavily weighted if } \\
\text { dietary data is deemed unreliable. }\end{array}$ \\
\hline $\begin{array}{l}\text { Accuracy of human measured height } \\
\text { and weight to calculate BMI to assess } \\
\text { body composition. }\end{array}$ & $\begin{array}{l}\text { Height and weight measures are obtained by } \\
\text { trained undergraduate teaching assistants under the } \\
\text { supervision of a graduate teaching assistant. Body } \\
\text { fat percentage was also measured using the } \\
\text { BodPod and can be used as an alternative to BMI } \\
29,31 \text {. }\end{array}$ \\
\hline $\begin{array}{l}\text { Total sample are breakfast } \\
\text { consumers, defined as more than or } \\
\text { equal to } 3 \text { days of breakfast intake }{ }^{33} \text {. }\end{array}$ & $\begin{array}{l}\text { Categorize breakfast consumers as those } \\
\text { consuming breakfast as those consuming at least } \\
\text { one day of breakfast intake }\end{array}$ \\
\hline $\begin{array}{l}\text { Total sample are breakfast skippers, } \\
\text { defined as less than or equal to } 3 \text { days } \\
\text { of breakfast intake }\end{array}$ & $\begin{array}{l}\text { Categorize breakfast skippers as those consuming } \\
\text { breakfast on } 0 \text { days }{ }^{4} \text {. }\end{array}$ \\
\hline
\end{tabular}


Appendix M: Table of Actions Taken to Manage Potential Pitfalls Identified in Thesis Proposal

\begin{tabular}{|c|c|c|}
\hline \multicolumn{3}{|c|}{$\begin{array}{c}\text { Actions Taken to Manage Potential Pitfalls of Study Outcomes Identified in Thesis } \\
\text { Proposal }\end{array}$} \\
\hline Pitfall & $\begin{array}{l}\text { Solution } \\
\end{array}$ & Action \\
\hline $\begin{array}{l}\text { Total sample categorized } \\
\text { as nighttime eaters, } \\
\text { defined as caloric intake } \\
\text { within } 4 \text { hours of sleep } \\
\text { onset or after 8:00PM } \\
3,5,32,33 \text {. }\end{array}$ & $\begin{array}{l}\text { Alter definition to only capture } \\
\text { those consuming calories within } \\
\text { two or one hour(s) of sleep onset, } \\
\text { or examine the cutoff point as } \\
9: 00,10: 00 \mathrm{PM} \text {, or later as } \\
\text { needed, for nighttime eating } \\
\text { categorization. }\end{array}$ & $\begin{array}{l}\text { Nighttime eating definition } \\
\text { was altered after computed } \\
\text { in multiple ways after } \\
\text { determining the most } \\
\text { statistically and dietary } \\
\text { significant categorizations. }\end{array}$ \\
\hline $\begin{array}{l}\text { Entire sample categorized } \\
\text { as non-nighttime eaters, } \\
\text { defined as no caloric } \\
\text { intake within } 4 \text { hours of } \\
\text { sleep onset or after } \\
\text { 8:00PM. }\end{array}$ & $\begin{array}{l}\text { Alter definition to capture those } \\
\text { consuming calories within five or } \\
\text { six hours of sleep onset, or } \\
\text { examine the cutoff point as } 8: 00 \text {, } \\
7: 00 \mathrm{PM} \text {, or earlier as needed, for } \\
\text { nighttime eating categorization. }\end{array}$ & $\begin{array}{l}\text { No action taken, pitfall did } \\
\text { not occur. }\end{array}$ \\
\hline $\begin{array}{l}\text { Accuracy of self-reported } \\
\text { FFQ, the DHQ }{ }^{38} \text {. }\end{array}$ & $\begin{array}{l}\text { The nutrition course material } \\
\text { includes portion estimation } \\
\text { lessons, this population enrolled } \\
\text { in this general nutrition course } \\
\text { has more background to estimate } \\
\text { portion sizes than a lay person. } \\
\text { The DHQ is not administered } \\
\text { until the } 10^{\text {th }} \text { week of the } \\
\text { academic semester, therefore } \\
\text { they have had } 10 \text { weeks of } \\
\text { exposure to general nutrition } \\
\text { information at a college level, } \\
\text { and short term portion size } \\
\text { lessons have been shown to } \\
\text { increase the accuracy of college- } \\
\text { aged students' portion size } \\
\text { estimates } 7 \text {. Measured variables } \\
\text { (biochemical and body fat } \\
\text { percentage) would be more } \\
\text { heavily weighted if dietary data } \\
\text { is deemed unreliable. }\end{array}$ & $\begin{array}{l}\text { Interpret results cautiously; } \\
\text { recommend future studies } \\
\text { utilize } 24 \text {-hour dietary } \\
\text { recall methods and } \\
\text { determine true reporters of } \\
\text { dietary intake by } \\
\text { measuring energy } \\
\text { expenditure via indirect } \\
\text { calorimetry to calculate } \\
\text { caloric capacity } 9,10 .\end{array}$ \\
\hline $\begin{array}{l}\text { Accuracy of human } \\
\text { measured height and } \\
\text { weight to calculate BMI } \\
\text { to assess body } \\
\text { composition. }\end{array}$ & $\begin{array}{l}\text { Height and weight measures are } \\
\text { obtained by trained } \\
\text { undergraduate teaching assistants } \\
\text { under the supervision of a } \\
\text { graduate teaching assistant. Body } \\
\text { fat percentage was also measured } \\
\text { using the BodPod and can be } \\
\text { used as an alternative to BMI } \\
29,31\end{array}$ & $\begin{array}{l}\text { Utilized BodPod data in } \\
\text { addition to BMI. }\end{array}$ \\
\hline
\end{tabular}




\begin{tabular}{|l|l|l|}
\hline $\begin{array}{l}\text { Total sample are } \\
\text { breakfast consumers, } \\
\text { defined as more than or } \\
\text { equal to 3 days of } \\
\text { breakfast intake }\end{array}$ & $\begin{array}{l}\text { Categorize breakfast consumers } \\
\text { as those consuming breakfast as } \\
\text { those consuming at least one day } \\
\text { of breakfast intake }\end{array}$ & $\begin{array}{l}\text { No action taken, pitfall did } \\
\text { not occur. }\end{array}$ \\
\hline $\begin{array}{l}\text { Total sample are } \\
\text { breakfast skippers, } \\
\text { defined as less than or } \\
\text { equal to 3 days of } \\
\text { breakfast intake }\end{array}$ & $\begin{array}{l}\text { Categorize breakfast skippers as } \\
\text { those consuming breakfast on 0 } \\
\text { days }^{4} \text {. }\end{array}$ & $\begin{array}{l}\text { No action taken, pitfall did } \\
\text { not occur. }\end{array}$ \\
\hline
\end{tabular}




\section{BIBLIOGRAPHY}

Alkerwi A, Baydarlioglu B, Sauvageot N, et al. Smoking status is inversely associated with overall diet quality: Findings from the ORISCAV-LUX study. Clin Nutr. 2016.

American College Health Association. American College Health AssociationNational College Health Assessment II: Reference Group Executive Summary Spring 2016 2016:21.

Andersen GS, Stunkard AJ, Sorensen TI, Petersen L, Heitmann BL. Night eating and weight change in middle-aged men and women. Int J Obes Relat Metab Disord. 2004;28(10):1338-1343.

Baron KG, Reid KJ, Kern AS, Zee P. Role of sleep timing in caloric intake and BMI. Obesity (Silver Spring). 2011;19(7):1374-1381.

Bo S, Musso G, Beccuti G, et al. Consuming more of daily caloric intake at dinner predisposes to obesity. A 6-year population-based prospective cohort study. PLoS One. 2014;9(9):e108467.

Boston RC, Moate PJ, Allison KC, Lundgren JD, Stunkard AJ. Modeling circadian rhythms of food intake by means of parametric deconvolution: results from studies of the night eating syndrome. Am J Clin Nutr. 2008;87:5.

Burke JD, Reilly RA, Morrell JS, Lofgren IE. The University of New Hampshire's Young Adult Health Risk Screening Initiative. J Am Diet Assoc. 2009;109(10):1751-1758.

Byrd-Bredbenner C, Schwartz J. The effect of practical portion size measurement aids on the accuracy of portion size estimates made by young adults. J Hum Nutr Diet. 2004;17:6.

Cluskey M, Grobe D. College weight gain and behavior transitions: male and female differences. J Am Diet Assoc. 2009;109(2):325-329. 
de Castro J. The time of day and the proportions of macronutrients eaten are related to total daily food intake. British Journal of Nutrition. 2007;98:6.

de Castro J. The Time of Day of Food Intake Influences Overall Intake in Humans. J Nutr. 2004;134:8.

Fleig D, Randler C. Association between chronotype and diet in adolescents based on food logs. Eat Behav. 2009;10(2):115-118.

Ford ES, Li C, Wheaton AG, Chapman DP, Perry GS, Croft JB. Sleep duration and body mass index and waist circumference among U.S. adults. Obesity (Silver Spring). 2014;22(2):598-607.

Galgani J, Ravussin E. Energy metabolism, fuel selection and body weight regulation. Int J Obes (Lond). 2008;32 Suppl 7:S109-119.

Gangwisch JE. Epidemiological evidence for the links between sleep, circadian rhythms and metabolism. Obes Rev. 2009;10 Suppl 2:37-45.

Garaulet M, Gomez-Abellan P, Alburquerque-Bejar JJ, Lee YC, Ordovas JM, Scheer F. Timing of food intake predicts weight loss effectiveness. Int J Obes (Lond). 2013;37(4):604-611.

Giannotti F, Cortesi F, Sebastiani T, Ottaviano S. Circadian preference, sleep and daytime behaviour in adolescence. J Sleep Res. 2002;11:8.

Gluck M, Venti C, Salbe A, Krakoff J. Nighttime eating: commonly observed and related to weight gain in an inpatient food intake study. Am J Clin Nutr. 2008;88:5.

Golley RK, Maher CA, Matricciani L, Olds TS. Sleep duration or bedtime? Exploring the association between sleep timing behaviour, diet and BMI in children and adolescents. Int J Obes (Lond). 2013;37(4):546-551.

Greaney ML, Less FD, White AA, et al. College students' barriers and enablers for healthful weight management: a qualitative study. J Nutr Educ Behav. 2009;41(4):281-286. 
Greene GW, Schembre SM, White AA, et al. Identifying clusters of college students at elevated health risk based on eating and exercise behaviors and psychosocial determinants of body weight. J Am Diet Assoc. 2011;111(3):394-400.

Gropper SS, Simmons KP, Connell LJ, Ulrich PV. Weight and Body Composition Changes during the First Three Years of College. J Obes. 2012;2012:634048.

Houston DK, Ding J, Nicklas BJ, et al. Overweight and obesity over the adult life course and incident mobility limitation in older adults: the health, aging and body composition study. Am J Epidemiol. 2009;169(8):927-936.

Kinsey AW, Ormsbee M. The health impact of nighttime eating: old and new perspectives. Nutrients. 2015;7(4):2648-2662.

Koebnick C, Smith N, Huang K, et al. OBAYA (obesity and adverse health outcomes in young adults): feasibility of a population-based multiethnic cohort study using electronic medical records. Population Health Metrics. 2012;10(15):8.

Mills JP, Perry CD, Reicks M. Eating frequency is associated with energy intake but not obesity in midlife women. Obesity (Silver Spring). 2011;19(3):552-559.

Morrell JS, Byrd-Bredbenner C, Quick V, Olfert M, Dent A, Carey G. Metabolic syndrome: comparison of prevalence in young adults at 3 land-grant universities. $J$ Am Coll Health. 2014;62(1):10.

Morrell JS, Lofgren IE, Burke J, Reilly R. Metabolic syndrome, obesity, and related risk ractors among college men and women. $J$ Am Coll Health. 2012;60(1):9.

Nelson MC, Story M. Food environments in university dorms: 20,000 calories per dorm room and counting. Am J Prev Med. 2009;36(6):523-526.

Ogden CL, Carroll MD, Kit BK, Flegal KM. Prevelance of obesity among adults: United States, 2011-2012. NCHS data brief 2013;131. 
Patel SR, Malhotra A, White DP, Gottlieb DJ, Hu FB. Association between reduced sleep and weight gain in women. Am J Epidemiol. 2006;164(10):947-954.

Raynor HA, Champagne CM. Position of the Academy of Nutrition and Dietetics: Interventions for the Treatment of Overweight and Obesity in Adults. J Acad Nutr Diet. 2016;116(1):129-147.

Reid KJ, Baron KG, Horn LV, Zee P. Contribution of evening macronutrient intake to total caloric intake and body mass index. Appetite. 2013;60(1):246-251.

Reid KJ, Baron KG, Zee PC. Meal timing influences daily caloric intake in healthy adults. Nutr Res. 2014;34(11):930-935.

Sato-Mito N, Sasaki S, Murakami K, et al. The midpoint of sleep is associated with dietary intake and dietary behavior among young Japanese women. Sleep Med. 2011;12(3):289-294.

Services. USDoHaH. The Surgeon General's Call to Action to Prevent and Decrease Overwt and Obesity. US Department of Health and Human Services Public Health Service. 2001:39.

Vadiveloo M, Dixon LB, Mijanovich T, Elbel B, Parekh N. Dietary variety is inversely associated with body adiposity among US adults using a novel food diversity index. $J$ Nutr. 2015;145(3):555-563.

van der Heijden AA, Hu FB, Rimm EB, van Dam RM. A Prospective Study of Breakfast Consumption and Weight Gain among U.S. Men. Obesity (Silver Spring). 2007;15:6.

Wang JB, Patterson RE, Ang A, Emond JA, Shetty N, Arab L. Timing of energy intake during the day is associated with the risk of obesity in adults. J Hum Nutr Diet. 2014;27 Suppl 2:255-262.

Winklebey MA, Cubbin C. Changing patterns in health behaviors and risk factors related to chronic diseases, 1990-2000. Behavior Change 2004;19(1):8. 